2016

\title{
Arbitrator Behaviour in Asymmetrical Adjudication (Part Two): An Examination of Hypotheses of Bias in Investment Treaty Arbitration
}

Gus Van Harten

Osgoode Hall Law School of York University, gvanharten@osgoode.yorku.ca

Follow this and additional works at: https://digitalcommons.osgoode.yorku.ca/olsrps

\section{Recommended Citation}

Van Harten, Gus, "Arbitrator Behaviour in Asymmetrical Adjudication (Part Two): An Examination of Hypotheses of Bias in Investment Treaty Arbitration" (2016). Osgoode Legal Studies Research Paper Series. 167.

https:// digitalcommons.osgoode.yorku.ca/olsrps/167 


\title{
OSGOODE HALL LAW SCHOOL \\ LEGAL STUDIES RESEARCH PAPER SERIES
}

\section{Arbitrator Behaviour in Asymmetrical Adjudication (Part Two): An Examination of Hypotheses of Bias in Investment Treaty Arbitration}

Osgoode Hall Law Journal, Vol. 53(2), 2016, Forthcoming.

\author{
Gus Van Harten
}

This paper can be downloaded free of charge from: http://ssrn.com/abstract=2721920

\begin{abstract}
Further information and a collection of publications from the Osgoode Hall Law School Legal Studies Research Paper Series can be found at:

http://www.ssrn.com/link/Osgoode-Hall-LEG.html
\end{abstract}

\section{Editors:}

Editor-in-Chief: Carys J. Craig (Associate Dean of Research \& Institutional Relations and Associate Professor, Osgoode Hall Law School, York University, Toronto)

Production Editor: Kiana Blake (Osgoode Hall Law School, York University, Toronto) 
Osgoode Legal Studies Research Paper No. 31

Vol. 12/ Issue. 7/ (2016)

\title{
Arbitrator Behaviour in Asymmetrical Adjudication (Part Two): An Examination of Hypotheses of Bias in Investment Treaty Arbitration
}

Osgoode Hall Law Journal, Vol. 53(2), 2016, Forthcoming.

Gus Van Harten

\begin{abstract}
:
This article reports on a study of potential systemic bias in the resolution of ambiguous legal issues by investment treaty arbitrators. It outlines tentative but significant findings that the arbitrators in general tended to favour (a) foreign investors over states in general, (b) foreign investors from major Western capital-exporting states over other foreign investors, and, albeit based on more limited data, (c) the U.S. as a respondent state over other respondent states. The evidence is derived from an extensive content analysis of the arbitrators' resolution of 14 legal issues that are contested among arbitrators or in secondary literature. The findings clearly supported initial expectations of systemic bias arising from unique incentives of the arbitrators. Yet the study also has important limitations and there is a range of possible explanations for the findings, some not raising concerns of inappropriate bias. Broadly, the findings lend support to perceptions that the design of investment treaty arbitration does not support fair and independent adjudication of the boundaries of sovereign authority and of disputes involving public funds.
\end{abstract}

\section{Keywords:}

Investment treaties, trade agreements, arbitration, discretion, bias

\section{Author(s):}

Gus Van Harten

Osgoode Hall Law School, York University

E: gvanharten@osgoode.yorku.ca 


\title{
Arbitrator Behaviour in Asymmetrical Adjudication (Part Two): An Examination of Hypotheses of Bias in Investment Treaty Arbitration
}

\author{
Gus Van Harten*
}

KEYWORDS: investment treaties, trade agreements, arbitration, discretion, bias

\begin{abstract}
This article reports on a study of potential systemic bias in the resolution of ambiguous legal issues by investment treaty arbitrators. It outlines tentative but significant findings that the arbitrators in general tended to favour (a) foreign investors over states in general, (b) foreign investors from major Western capital-exporting states over other foreign investors, and, albeit based on more limited data, (c) the U.S. as a respondent state over other respondent states. The evidence is derived from an extensive content analysis of the arbitrators' resolution of 14 legal issues that are contested among arbitrators or in secondary literature. The findings clearly supported initial expectations of systemic bias arising from unique incentives of the arbitrators. Yet the study also has important limitations and there is a range of possible explanations for the findings, some not raising concerns of inappropriate bias. Broadly, the findings lend support to perceptions that the design of investment treaty arbitration does not support fair and independent adjudication of the boundaries of sovereign authority and of disputes involving public funds.
\end{abstract}

Associate Professor, Osgoode Hall Law School of York University. 
A heading: Introduction

Investment treaty arbitration, also known as investor-state dispute settlement (ISDS), is a uniquely powerful form of international adjudication that protects foreign investors from countries. Investment treaty arbitration has attracted public attention in recent years as governments in North America and Europe have pressed to expand its role, most significantly in proposed trade agreements among developed countries. Since the late 1960s (especially in the 1990s), investment treaty arbitration has been incorporated into bilateral investment treaties (BITs) between a developed and a developing or transition country or, alternatively, among developing and transition countries. However, only one Western developed country, Canada, has yet agreed to investment treaty arbitration with the United States (in the North American Free Trade Agreement $(\mathrm{NAFTA})^{1}$ ) and, besides NAFTA, only one other agreement, the Energy Charter Treaty, ${ }^{2}$ has applied investment treaty arbitration among developed countries and, in that treaty, its role was limited to the energy sector. The push to expand investment treaty arbitration in the Europe-U.S. Transatlantic Trade and Investment Partnership (TTIP), the Canada-Europe Comprehensive Economic and Trade Agreement (CETA), and the U.S.-led Trans-Pacific Partnership (TPP), in particular, signals a turning point in the position of investment treaty arbitration. It would establish investment treaty arbitration as a near-global institution for regulating and disciplining countries in order to protect multinational companies and very

\footnotetext{
${ }^{1}$ North American Free Trade Agreement (NAFTA) (17 December 1992; entered into force 1 January 1994) 32 ILM 296 and 605.

${ }^{2}$ Energy Charter Treaty (annex I of the Final Act of the European Energy Charter Conference) (Lisbon, 17 December 1994) 34 ILM 373.
} 
wealthy individuals, who are the foreign investors that have received the great bulk of the public compensation ordered in investment treaty arbitration.

Investment treaty arbitration is an exceptional form of adjudication. ${ }^{3}$ It is unique in its use of a for-profit asymmetrical model of adjudication to resolve finally questions about sovereign authority and public compensation for private actors. The model is for-profit because arbitrators are appointed and paid by the case rather than for a set term with a secure tenure and salary. It is asymmetrical because only one class of claimants brings claims against the other. Investment treaty arbitration also incorporates the exceptionally powerful remedy of an unlimited retrospective damages award against the state, for its sovereign activities, that becomes widely enforceable against the state's assets in other countries with limited or no prospect for judicial review. These features are fundamental to the design of investment treaty arbitration and they are present in all of the versions of ISDS now proposed by governments for agreements such as the TTIP, CETA, and TPP. These features also create a useful context in which to examine hypotheses of bias arising from the evident incentives of arbitrators.

For the present study, it was expected that arbitrators would favour some actors over others due to their interest in re-appointment and in expanding the role of the arbitration industry and that this might help explain arbitrator behaviour. The expectation was tested through the systematic coding of 14 legal issues and how they were resolved by arbitrators in situations where the arbitrators faced silence or ambiguity in an investment treaty. The hypotheses were that the arbitrators would tend to favour expansive (favouring the claimant investor) over restrictive

\footnotetext{
${ }^{3}$ For a detailed outline, see Gus Van Harten, Investment Treaty Arbitration and Public Law (Oxford: OUP, 2007).
} 
(favouring the respondent state) resolutions of issues, that this tendency would increase where the claimant was from a major capital-exporting state, and that the tendency would decrease where the respondent was a major capital-exporting state.

The study is based on a systematic content analysis ${ }^{4}$ of publicly-available awards dealing with jurisdictional matters in 140 known cases under investment treaties. The awards were coded for resolutions by arbitrators of a series of jurisdictional and substantive legal issues that were contested in existing awards or secondary literature. The coded data was used to test three hypotheses developed in advance based on the expectations about arbitrator interests arising from the system's unique structure. In this article, the results of the second phase of the study are examined. The second phase involved systematic coding - as expansive, restrictive, or nonclassifiable - of resolutions by arbitrators of seven substantive issues. The first phase, reported previously, ${ }^{5}$ involved coding of seven jurisdictional issue resolutions. In that phase, it was found that there was a tendency toward expansive resolutions that enhanced the compensatory promise of the system for claimants and that this tendency was accentuated where the claimant was from a Western capital-exporting state. The latter finding focused on claimants from the U.S., the U.K., France, and Germany (although German claimants were an apparent exception to the overall tendency for the group) and was supported by additional analyses of other Western capital-exporting state groupings.

\footnotetext{
${ }^{4}$ Mark A. Hall and Ronald F. Wright, "Systemic Content Analysis of Judicial Opinions - Appendix" (2008) 95 California Law Review 63 Supp.

${ }^{5}$ G.Gus Van Harten, “Arbitrator Behaviour in Asymmetrical Adjudication: An Empirical Study of Investment Treaty Arbitration" (2012) 50 OHLJ 211.
} 
In the second phase of the study, reported here, it was confirmed that the arbitrators tended to adopt an expansive approach favouring claimants and that the tendency was accentuated for the grouping of U.S., U.K., French, and German claimants. Perhaps most notably, it was also found, based on the cumulative results of both phases, that there was a reduced tendency toward expansive resolutions where the respondent was the U.S. as an example of a major capitalexporter. This tendency was observed in relation to the U.S. experience as a respondent faced with claims by Canadian investors under the NAFTA. It had not been possible in phase one to test reliably the hypothesis that arbitrators would favour restrictive approaches if the respondent was a major Western capital-exporter due to lack of data. Finally, it was found that, where an arbitrator was frequently appointed, there was an accentuated tendency toward expansive resolutions of jurisdictional issues but such a tendency was not found for substantive issues.

These findings in phase two of the study support the original hypotheses of bias, especially in favour of the U.S. via its nationals acting as claimants and its status as a respondent state. The evidence did not prove such bias because in social scientific research there are always other possible explanations for findings; i.e. correlation does not mean causation. Even so, it was surprising to find significant evidence of the role of claimant nationality and respondent identity in predicting the behaviour of arbitrators when they are faced with silence or ambiguity in an investment treaty. Because they involve the resolution of legal questions, the observed variations in resolutions seem unlikely to be explained by some untested factors that may drive case 
outcomes, such as factual differences among cases. ${ }^{6}$ Whatever the explanation for the results, the evidence tentatively supports perceptions that investment treaty arbitration is not fair and independent.

\section{A heading: Overview of the study}

In examining hypotheses of bias in investment treaty arbitration, the study focused on two sets of actors on whom the arbitrators appear dependent due to the institutional context in which they operate: prospective claimants and major capital-exporting states. The influence of prospective claimants stems from their power to initiate the use of the system in all cases and from the wider role of foreign investors (especially major companies) as arbitration users, indirect participants in decision-making at arbitration bodies such as the International Chamber of Commerce, and negotiators of investment contracts containing arbitration clauses. ${ }^{7}$ The influence of major states stems from their role in negotiating investor-state arbitration in investment treaties and from their relative power in arbitration bodies such as the International Centre for Settlement of Investment Disputes (ICSID) and Permanent Court of Arbitration, where they choose or nominate the officials who in turn choose the individuals who will sit as arbitrators case-by-case where the

\footnotetext{
${ }^{6}$ B. Leiter, "Rethinking Legal Realism: Toward a Naturalized Jurisprudence" (1997) 76 Texas L Rev 267 at 269; J.

P. Kastellec, "The Statistical Analysis of Judicial Decisions and Legal Rules with Classification Trees" (2010) 7 J Empirical Legal Studies 202 at 205-6.

${ }^{7}$ G. Van Harten, "Investment Treaty Arbitration, Procedural Fairness, and the Rule of Law" in S. Schill (ed.) International Investment Law and Comparative Public Law (Oxford University Press, 2010).
} 
parties do not agree or who choose the person or organization that exercises this arbitrator appointment power case-by-case. ${ }^{8}$

These expectations were derived from wider claims about perceived or actual bias in investment treaty arbitration. Such claims have been made by various commentators who have expressed concern that investment treaty arbitration favours foreign investors, corporations, G-8 countries, Western countries, or capital-exporting countries and dis-favours governments, the public, Third World states, developing countries, capital-importing countries, or low or middle-income countries. For example, Bernasconi-Osterwalder argued that a pro-investor imbalance arose in the system because investors can bring claims against host states but not vice versa $;{ }^{9}$ Chung argued that developing countries are disadvantaged in investor-state arbitration in contrast to industrialized, developed nations; ${ }^{10}$ Stewart raised concerns about pro-Western bias; ${ }^{11}$ Odumosu referred to the number of claims against Third World developing countries as opposed to capital exporting states and the industrialized West; ${ }^{12}$ and Bolivian President Evo Morales reportedly claimed bias in ICSID arbitration in favour of transnational companies and against governments

\footnotetext{
${ }^{8}$ Ibid.

${ }^{9}$ N. Bernasconi-Osterwalder, "Who Wins and Who Loses in Investment Arbitration? Are Investors and Host States on a Level Playing Field?” (2005) 6 J World Investment and Trade 69 at 69.

${ }^{10}$ O. Chung, "The Lopsided International Investment Law Regime and Its Effect on the Future of Investor-State Arbitration" (2007) 47 Virg J Int'l Law 953 at 963-936.

${ }^{11}$ E. Stewart, "Arbitration in the Developing World" (7 January 2008) Presentation to Conference 21: Cotrina 2008 Legal Conference at 3 and 8.

${ }^{12}$ I. T. Odumosu, "The Antinomies of the (Continued) Relevance of ICSID to the Third World" (2007) 8 San Diego Int'l LJ 345 at 346-348, 364, and 371-372.
} 
other than the U.S. ${ }^{13}$ The present study is not apposite to all of these claims. It was designed to test expectations of suspected bias in favour of foreign investors as claimants and in favour of major capital-exporting states, including the U.S., as respondents or via a state's nationals acting as claimants. In other words, it was designed to test whether arbitrators would favour claimants in general, whether they would favour claimants especially when they were associated with a major state, and whether they would soften their approach by disfavouring claimants when the claim was against a major state (i.e. the U.S.) despite the arbitrators' apparent incentive to favour claimants in general.

The study was based on a systematic content analysis ${ }^{14}$ of all publicly-available decisions by investment treaty arbitrators in the 140 known cases under investment treaties to May 2010 , when the coding process began. The decisions were coded for resolutions by arbitrators of 14 legal issues that were contested to that point in arbitrators' decisions or secondary literature. The cumulative results for these 14 issues, across a total of 1001 issue resolutions per arbitrator, indicated a strong tendency toward resolutions that enhanced the compensatory promise of investment treaty arbitration for foreign investors and its financial risks for states. This tendency was accentuated where the claimant had the nationality of a major Western capital-exporter, it appears especially — based on variables controlled for in the model—where the claim was under

\footnotetext{
13 “Evo Morales plantea buscar fórmula para neutralizar el CIADI” (Press report, El Economista, 29 April 2007), http://ecoaula.eleconomista.es/empresas-finanzas/noticias/204986/04/07/Evo-Morales-plantea-buscar-formula-paraneutralizar-el-CIADI.html (last accessed 1 December 2014) (“En estos pleitos siempres los ganan las transnacionales nunca ganan los gobiernos. El único gobierno que ganó una vez fue el de EE.UU.”).

${ }^{14}$ Hall and Wright, supra note 4.
} 
a bilateral investment treaty (BIT) or the Energy Charter Treaty (ECT); where the claim involved any of 11 of the 14 issues coded; and, with respect to jurisdictional issues, where the claim was resolved by frequently-appointed arbitrators. The tendency was reduced where the claim was against the U.S., although this finding was based on a more limited number of issue resolutions and, in all instances, involved claims against the U.S. by Canadian investors under NAFTA.

The study has important limitations. It does not establish evidence of actual bias on the part of any individual or in any particular case. ${ }^{15}$ There is a range of possible explanations, some not entailing any inappropriate bias, and further inferences are needed to connect the observed tendencies to the study's underlying rationales. There are important limitations in the coding process and analytical tools and, overall, in the use of quantitative methods to examine potential adjudicative bias. ${ }^{16}$ The amount of data (issue resolutions) and thus the robustness of the findings varied for the different hypotheses. The most reliable finding is the new and cumulative one that the observed tendencies appear to exist in the coded data, that they apply both to jurisdictional and substantive issues, and that they are unlikely to be explained by chance.

\section{A heading: Theoretical background}

\footnotetext{
${ }^{15}$ G. C Sisk and M. Heise, "Judges and Ideology: Public and Academic Debates About Statistical Measures” (2005) 99 Nw U L Rev 743 at 794; D. E. Bloom, "Empirical Models of Arbitrator Behavior Under Conventional Arbitration" (1986) National Bureau of Economic Research Working Paper No. 1841.

${ }^{16}$ Hall and Wright, supra note 4 at 87-8; K. Krippendorf, Content Analysis: An Introduction to Its Methodology (Newbury Park: Sage Publications, 1980) 22; C. G. G. Aitken and F. Taroni, "Fundamentals of statistical evidence a primary for legal professionals" (2008) 12 Int'l J Evidence and Proof 181 at 203.
} 
A more detailed outline of the theoretical basis for the study is provided elsewhere. ${ }^{17}$ In summary, the unconventional structure of investment treaty arbitration provides a unique context for testing expectations of adjudicator behaviour. The system of investment treaty arbitration is unique because it uses arbitration to resolve corporate and individual claims against the state in its sovereign capacity. ${ }^{18}$ In domestic legal systems, such disputes are resolved ultimately in courts not by arbitrators. Conventionally, in international law, the use of arbitration to resolve such disputes would be based on a framework of reciprocal state-to-state dispute resolution. The same basic reciprocal framework applies to the arbitration of commercial disputes. In rare situations where individuals can sue states directly in international law, such as at the European courts, the disputes are resolved by international courts. ${ }^{19}$

Thus, in contrast to other forms of arbitration, ${ }^{20}$ investment treaty arbitration is non-reciprocal because investors can sue sovereign states directly under a treaty and cannot themselves be sued (other than in the limited and hypothetical circumstances of a permissible counter-claim by a state). Further, the system does not employ the usual safeguards of judicial independence otherwise present in domestic and international courts, such as secure tenure, an objective means of case assignment, and restrictions on outside remuneration by the judge. Instead, arbitrators are appointed and paid by the case, assigned to specific cases by the parties or by executive officials,

\footnotetext{
${ }^{17}$ Van Harten, supra note 5 at 219-21.

${ }^{18}$ ibid at 217 (note 24).

${ }^{19}$ Van Harten, supra note 3 , ch 3.

${ }^{20}$ Bloom, supra note 11 at 3.
} 
and allowed to work on the side as lawyers who advise clients that may have an interest in how the treaties are interpreted by the arbitrators. ${ }^{21}$

The broad question in this study was how this unique combination of structure and function may affect arbitrator behaviour. The system's asymmetrical structure and absence of conventional institutional safeguards creates apparent incentives for arbitrators to favour the class of parties (investors, especially deep-pocketed ones) that are able to trigger use of the system and appointment of arbitrators. ${ }^{22}$ Arbitrators may also be influenced by an interest to appease those with power over arbitrator appointments or with influence over the position of the arbitration industry more broadly. ${ }^{23}$ It is certainly not suggested that these expectations are the only possible factors that may influence arbitrator behaviour. A range of factors and complex interactions is undoubtedly present in the thought process of adjudicators and in the deliberations of a tribunal. Yet, the economic factors isolated here do reflect issues of rational self-interest and marketability that have been identified by commentators as playing a role in arbitration and are connected to the suspicions of bias identified earlier. ${ }^{24}$

\footnotetext{
${ }^{21}$ Van Harten, supra note 7.

${ }^{22}$ Ibid. C. R. Drahozal, “Judicial Incentives and the Appeals Process” (1998) 51 SMU L Rev 469 at 500 and 503; N. B. Majeed, "Investor-State Disputes and International Law: From the Far Side" (2004) 98 ASIL Proceedings 30 at 31.

${ }^{23}$ W. Mattli, "Private Justice in a Global Economy: From Litigation to Arbitration" (2001) 55 Int'l Org 919 at 921 2.

${ }^{24}$ Supra notes 1-5. A. S. Rau, "Integrity in Private Judging" (1997) 38 S Tex L Rev 485 at 521-2.
} 
The project sought to test three a priori hypotheses. ${ }^{25}$ The first was that investment treaty arbitrators, when exercising their discretion to resolve contested legal issues, would tend to adopt expansive (favouring the claimant investor) over restrictive (favouring the respondent state). This expectation flowed from apparent incentives of arbitrators to encourage claims by signalling to prospective claimants that claims are reasonably likely to succeed. ${ }^{26}$ The second and third hypotheses were, respectively, that the expected tendency toward expansive approaches would be accentuated in cases brought by claimants from a major Western capital-exporting state, represented primarily by the grouping of France, Germany, the U.K., and the U.S., and that the tendency would be lessened in cases against any of those four countries. ${ }^{27}$ These hypotheses were based on expectations that arbitrators would be more responsive to interests of major Western capital-exporting states due to the relative influence of those states in institutions that have default power to appoint arbitrators and due to their role as the primary drivers of the treaty models on which investment treaties are based including their widespread reliance on investorstate arbitration. $^{28}$

A heading: Methodology and its limitations

\footnotetext{
${ }^{25}$ For other potential hypotheses identified in the planning of the project, and for an outline of the author's preconceptions on the hypotheses, see Van Harten, supra note 5 at 224-225.

${ }^{26}$ B. Trujillo, "Regulating Bankruptcy Abuse: An Empirical Study of Consumer Exemptions Cases" (2006) 3 J Empir Legal Studies 561 at 576.

${ }^{27}$ On why these states were identified as the primary measure of major Western capital-exporters, see Van Harten, supra note 5 at 225 (note 48 ).

${ }^{28}$ Van Harten, supra note 5 at 216-221.
} 
Fourteen issues were selected at the outset for coding with the aim of covering a reasonable range of contested jurisdictional and substantive issues under the treaties that allow investor-state arbitration. They were identified based on a review of existing awards (i.e. decision) and secondary literature and in consultation with outside legal experts. ${ }^{29}$ The coded issues included seven jurisdictional issues in phase one and seven substantive issues in phase two. ${ }^{30}$ The combined results for all 14 issues offered the most robust basis for testing the hypotheses. The methodology for identifying contested issues - and for outlining expansive or restrictive resolutions of each issue - and the process for coding the seven jurisdictional issues is discussed elsewhere. ${ }^{31}$ Those seven jurisdictional issues were the following:

1. Corporate person investor - should a claim be permissible where ownership of the investment extends through a chain of companies running from the host to the home state via a third state? Expansive approach: yes. Restrictive approach: no.

2. Natural person investor - should a claim be permissible where brought by a natural person (a) against the only state of which the person is a citizen or (b) against a state of which the person is a citizen without confirmation of dominant and effective nationality? Expansive

\footnotetext{
${ }^{29}$ Van Harten, supra note 5 at 228.

${ }^{30}$ A contested issue relating to one substantive standard, MFN treatment, was coded under jurisdictional issues because it related primarily to a tribunal's authority to hear a claim by using MFN treatment to transfer dispute settlement provisions from one treaty to another.

${ }^{31}$ Van Harten, supra note 5 at 225-227.
} 
answer: yes to either of the two questions. Restrictive approach: no to either of the two questions.

3. Investment - should the Fedax criteria $^{32}$ be applied to limit the concept of investment under the Convention on the Settlement of Investment Disputes Between States and Nationals of Other States (ICSID Convention); ${ }^{33}$ or, regardless of whether under the ICSID Convention, should there be a requirement for an actual transfer of capital into the host state as a feature of an investment; or should the concept of investment be limited to traditional categories of ownership? Expansive approach: no to any of the three questions. Restrictive approach: yes to any of the three questions.

4. Minority shareholder interests - should a claim by a minority shareholder be allowed where the treaty does not permit claims by minority shareholders, such as where the treaty does not include the term "shares" in the definition of investment, or should it be permitted without limiting the claim to the shareholder's interest in the value and disposition of the shares (as opposed to interests of the domestic firm itself)? Expansive approach: yes to either of the two questions. Restrictive approach: no to either of the two questions.

\footnotetext{
${ }^{32}$ Fedax NV v. Republic of Venezuela (1997), 37 ILM 1378 (International Centre for Settlement of Investment Disputes).

${ }^{33}$ Convention on the Settlement of Investment Disputes Between States and Nationals of Other States, 18 March 1965, ICSID/15, 4 ILM 524 (entered into force 14 Oct 1966) [ICSID Convention].
} 
5. Permissibility of investment - should there be an evident onus placed on the claimant (or the respondent state) to show that an investment was (or was not) affirmatively approved or was (or was not) based on corrupt practices? Expansive approach: onus on the respondent state. Restrictive approach: onus on the claimant.

6. Parallel claims - should a claim be allowed in the face of a treaty-based duty to resort to local remedies that clearly was not satisfied by the claimant; in the face of a contractually-agreed dispute settlement clause relating to the same factual dispute; in the face of an actual claim, arising from the same factual dispute, via the relevant path of a treaty-based fork-in-road clause; ${ }^{34}$ or in the face of an actual claim, arising from the same factual dispute, via another treaty that could lead to a damages award in favour of the investor. Expansive approach: yes to any of the four questions. Restrictive approach: no to any of the four questions.

7. Scope of most-favoured-nation treatment - should the concept of most-favoured-nation treatment be extended to non-substantive provisions of other treaties (such as dispute settlement provisions)? Expansive approach: yes. Restrictive approach: no.

The focus in this article is on the cumulative findings and coding of the substantive issues, all of which arose from silence or ambiguity in the treaties' relevant provisions. The issues were coded using pre-set guidelines reproduced in detail in Appendix One with footnotes to indicate the

\footnotetext{
${ }^{34} \mathrm{~A}$ fork-in-the-road clause requires an investor to choose between pursuing one or two (or more) paths, such as domestic courts and investment treaty arbitration, that may be available to adjudicate the dispute with the host state.
} 
sources that were used to model expansive and restrictive approaches. In summary, the coded substantive issues were: ${ }^{35}$

8. National treatment - can this standard be breached where the compared foreign and domestic investors are not in like circumstances, where the like circumstances are established based only on the existence of a competitive relationship between the compared investors, or where there is only limited evidence of de facto discrimination or protectionist intent? Expansive approach: yes to any of the sub-questions; restrictive approach: no to any of the subquestions.

9. Fair and equitable treatment (FET) (autonomous standard) - is this standard autonomous of customary international law? Expansive approach: yes; restrictive approach: no.

10. FET (content) - does this standard encompass a novel conception of the state's obligations indicated by terms such as idiosyncratic, unreasonable, legitimate expectations, stability of the legal or business framework, affirmative transparency obligations, or breach of another international obligation - beyond the conventional Neer and ELSI terminology of outrage, bad faith, wilful disregard of due process of law, wilful neglect of duty, etc.? ${ }^{36}$ Expansive approach: yes; restrictive approach: no.

\footnotetext{
${ }^{35}$ The substantive issues are numbered 8 to 14 to distinguish them from the jurisdictional issues reported previously, ibid.

${ }^{36}$ Neer Claim (United States v Mexico) (1926) 4 RIAA 60 [Neer]; Elettronica Sicula SpA (United States v Italy) [1989] ICJ Rep 14 [ELSI].
} 
11. Full protection and security - does this standard go beyond issues of physical security to include issues of legal security or stability of the investment climate or does the standard assign full responsibility to the state where a foreign investor suffers physical harm without any discussion of a surrounding context of severe longstanding conflict in a country? Expansive approach: yes to either sub-question; restrictive approach: no to either subquestion.

12. Indirect expropriation - is the standard breached based solely or primarily on the effect of a measure rather than other potentially relevant factors, based on the measure's effects being significant or substantial taking as opposed to a near-complete taking, or based on conceptual severance of the affected property right or economic interest? Expansive approach: yes to any of the sub-questions; restrictive approach: no to any of the sub-questions.

13. Umbrella clause - can this standard be violated by private or commercial acts in addition to public or sovereign acts of the state? Expansive approach: yes; restrictive approach: no.

14. National security exception - does this exception exclude emergency measures to address a domestic financial and economic crisis? Expansive approach: yes; restrictive approach: no.

Where an issue was found to have arisen in a tribunal's award, each arbitrator's resolution of the issue was classified as expansive, restrictive, or non-classifiable. The expansive and restrictive approaches for each issue reflected positions that enhanced or reduced the compensatory promise 
of the system for claimants and the risk of liability for states. Non-classifiable situations included resolutions that, as explained in the award, did not fall reasonably within the scope of an expansive or restrictive approach in the coding guidelines. Non-classifiable situations also included instances in which the claim or argument was withdrawn by a party, the tribunal found it unnecessary to resolve the issue, or the issue appeared to have been resolved specifically and expressly by the treaty. In the latter situation, the resolution of the issue was not coded as expansive or restrictive because it was not considered a sufficient exercise of arbitrator discretion.

The primary data source was the text of arbitrators' awards (and other decisions) in all known investment treaty cases decided by 10 May 2010 and publicly-available by 1 June $2010 .{ }^{37}$ In summary, descriptive information on known cases was initially double-coded, but not blindly, by law students/ research assistants over a three-year period. A more involved coding process was then used to determine whether an issue had arisen and, if so, whether its resolution appeared expansive or restrictive. Cases were double-coded, although not blindly, by a law student/ research assistant and by the author. One student coded all jurisdictional issues in the first phase of the project; a different student coded all of the substantive issues in the second phase. In both

\footnotetext{
37 The coding process is outlined in more detail in Van Harten, supra note 5 at 225-227. A case was "known" (1) where it was listed on the Investment Treaty Arbitration website (www.italaw.com) with an indication that it was brought under an investment treaty or (2) where it was listed as a treaty-based case on any of the websites of ICSID, the Permanent Court of Arbitration, the Energy Charter Treaty Secretariat, or the governments of Canada, Mexico or the U.S. A case was "publicly-available" where a decision on any jurisdictional or substantive issues was posted on the Investment Treaty Arbitration website mentioned above.
} 
phases, disagreements over coding were resolved on an anonymous basis by a third coder who was a research assistant and lawyer familiar with international investment law. It was stressed to all coders that they should form autonomous opinions when making coding decisions.

The methodology for identifying issue resolutions, as summarized here, is subject to important characteristics and limitations. It focused on a sample of jurisdictional and substantive issues meaning that other aspects of arbitrator discretion were excluded from the study. Any issues or resolutions not outlined in the text of an award could not be captured by the coding. ${ }^{38}$ The study covered all available cases to the date when coding began yet some materials in known cases were not public and, in an unknown number of totally secret cases such as at the International Chamber of Commerce's Court of International Arbitration, it is not possible to verify publicly that an investor-state claim was brought and decided by arbitrators at all. The study tested expectations at a systemic level - observable in overall the decision-making of arbitrators - but was not designed to test for actual bias on the part of any specific arbitrator. ${ }^{39}$

For substantive issues, inter-coder reliability among the first and second coders was $78.5 \%$ on whether an issue had arisen for coding as expansive or restrictive and $98.9 \%$ on whether the issue resolution should be coded as expansive or restrictive (each compared to a random chance of reliability of 50\%). Even so, coder discretion was integral despite the steps taken to limit it

\footnotetext{
${ }^{38}$ Hall and Wright, supra note 4 at 100.

${ }^{39}$ L. B. Bingham, “On Repeat Players, Adhesive Contracts, and the Use of Statistics in Judicial Review of Employment Arbitration Awards” (1998) 29 McGeorge L Rev 223 at 259.
} 
and double coding was not blind. ${ }^{40}$ For purposes of transparency and replication, the coding guidelines for the project are appended and issue-by-issue coding notes, which provided the basis for coding inferences, are publicly-available. ${ }^{41}$

Overall, the study establishes approximate correlations not firm conclusions. ${ }^{42}$ The study identified significant evidence to support the hypotheses but it is only a single study based on a particular method. Perhaps most importantly, although incidentally to the immediate project, the inherent uncertainty of any study on possible adjudicative bias reinforces the case for safeguards of independence at the institutional level to protect against reasonably perceived as well as actual bias.

\section{A heading: Dataset}

In total, 261 cases were identified as having been decided as of 10 May 2010 and publiclyavailable in English as of 1 June 2010, when coding for the project began. Of these, 174 cases had led to at least one award that dealt with any jurisdictional or substantive issues. In 21 of the 174 cases, an award was not publicly-available. In another eight cases, an award was not

\footnotetext{
${ }^{40}$ Hall and Wright, supra note 4 at 109; M. Evans et al, "Recounting the Courts? Applying Automated Content Analysis to Enhance Empirical Legal Research” (2007) 4 J Empirical Legal Studies 1007 at 1008-1009.

${ }^{41}$ The coding notes will be posted on the Social Science Research Network under the author's name following publication of this article: http://ssrn.com/author=638855.

${ }^{42}$ M. Hall, "Randomness Reconsidered: Modeling Random Judicial Assignment in the U.S. Courts of Appeals" (2010) 7 J Empirical Legal Studies 574 at 574-5.
} 
available in English. Another three cases had been consolidated with another case and were coded under the consolidated case. This left 142 cases that could be coded as publicly-available English-language awards on jurisdictional or substantive matters in known cases that had led at least to an award on jurisdiction by the cut-off dates for the study. The cases arose primarily under bilateral investment treaties (78\%) and secondarily under NAFTA (14\%), the ECT (6\%), and the ASEAN Agreement for the Promotion and Protection of Investments (1\%). ${ }^{43}$ In 12 of the 142 cases, no jurisdictional or substantive issue was found to have arisen, leaving 130 cases in which one or more issues had arisen. Of these, there were 123 cases in which at least one issue was resolved expansively or restrictively by one or more arbitrators.

The same dataset was used for the coding of substantive and jurisdictional issues although a different range of cases in the dataset proved relevant to each type of issue. For the substantive issues, 80 cases were available for content analysis while for the jurisdictional issues 140 cases were available. This was because, in 25 cases, jurisdiction was denied to the claimant thus precluding an award on any substantive issue and, in another 40 cases, no award on substantive issues was available by the cut-off date for the study. Of the 80 cases that could be coded for substantive issues, there were 65 in which one or more substantive issues arose and, in all of those cases, at least one issue was found to have been resolved restrictively or expansively.

\footnotetext{
${ }^{43}$ Agreement among the Government of Brunei Darussalam, the Republic of Indonesia, Malaysia, the Republic of the Philippines, the Republic of Singapore and the Kingdom of Thailand for the Promotion and Protection of Investments (ASEAN Agreement for the Promotion and Protection of Investments) (Manila, 15 December 1987) 27 ILM 612.
} 
A heading: Analytical model

The analytical model for the study was developed using eight primary measures of interest, a dependent variable, and seven covariates used to test the hypotheses. ${ }^{44}$ In the statistical model, the primary measures of interest were as follows.

Nationality of claimant. Claimants in the dataset had nationality of 26 different states.

Identity of respondent state. There were 47 states among the respondents in the dataset.

For these first two measures, the second and third hypotheses were tested primarily by isolating France, Germany, the U.K., and the U.S. - as a group - in comparison to all other states. These supplementary groupings of states were also analysed to provide alternative measures of Western capital-exporting interests:

- U.K. and U.S. versus all others;

- France, Germany, and U.K. versus all others (except U.S.);

- historical G-7 members ${ }^{45}$ versus all others;

\footnotetext{
${ }^{44}$ The regression analysis was done by a statistician and research assistant, Heather Krause, who was asked to test the data rigorously and avoid assumptions that could skew the analysis in favour of the study's hypotheses. A law student and former statistical analyst, Kelly Goldthorpe, advised on project design and conducted initial data analysis.

${ }^{45}$ Canada, France, Germany, Italy, Japan, U.K., and U.S.
} 
- Western European former colonial powers ${ }^{46}$ versus all others (except U.S.);

- UN geographic classifications of states in North America, Western Europe, Northern Europe, and Southern Europe ${ }^{47}$ versus all others;

- UN classification of states in Eastern Europe ${ }^{48}$ versus all others (except North America, Western Europe, Northern Europe, and Southern Europe);

- $\quad$ OECD members as of $1990^{49}$ versus all others;

- OECD members as of $2000^{50}$ versus all others;

- World Bank classification of high income countries as of $1990^{51}$ versus all others; and

- World Bank classification of high income countries as of $2000^{52}$ versus all others.

${ }^{46}$ Belgium, Denmark, France, Germany, Italy, Netherlands, Portugal, Spain, Sweden, and U.K.

${ }^{47}$ Albania, Austria, Belgium, Bermuda, Bosnia, Canada, Croatia, Denmark, Estonia, Finland, France, Germany, Gibraltar, Greece, Greenland, Ireland, Italy, Latvia, Liechtenstein, Lithuania, Luxembourg, Macedonia, Malta, Monaco, Netherlands, Norway, Portugal, Serbia, Slovenia, Spain, Sweden, Switzerland, U.K., and U.S.

${ }^{48}$ Belarus, Bulgaria, Czech Republic, Hungary, Moldova, Poland, Romania, Russia, Slovakia, and Ukraine.

${ }^{49}$ Australia, Austria, Belgium, Canada, Denmark, Finland, France, Germany, Greece, Iceland, Ireland, Italy, Japan, Luxembourg, Netherlands, New Zealand, Norway, Portugal, Spain, Sweden, Switzerland, Turkey, U.K., and U.S.

${ }^{50}$ Czech Republic, Hungary, Mexico, Poland, Slovakia, and South Korea, and all OECD members as of 1990 (ibid).

${ }^{51}$ Andorra, Aruba, Australia, Austria, Bahamas, Belgium, Bermuda, Brunei, Canada, Cyprus, Denmark, Finland, France, Germany, Greenland, Hong Kong, Iceland, Ireland, Israel, Italy, Japan, Kuwait, Luxembourg, Netherlands, New Zealand, Norway, Qatar, Singapore, Spain, Sweden, Switzerland, Taiwan, United Arab Emirates, U.K., and U.S.

${ }^{52}$ Barbados, Cayman Islands, Greece, Guam, Liechtenstein, Malta, Monaco, Portugal and Slovenia, and all high income countries as of 1990 (ibid). 
Importantly, for the third hypothesis involving claims against capital-exporting states, the only one of the four major Western capital-exporting states against whom claims had been brought was the U.S., which was then compared to a range of groupings of other states. For this reason, the findings on this third hypothesis are relevant statistically only to the U.S. They may be relevant to other capital-exporting states from a practical or theoretical perspective but not for statistical purposes. Thus, there is no basis to predict what may happen in claims against those other capital-exporting states based on the findings in this study.

Treaty/ treaty type. There were four treaties or treaty types represented in the data: BITs, NAFTA, the ECT, and the ASEAN investment agreement. The model excluded the last of these because it arose in only one case. Issue resolutions reached under the other three treaties were analyzed cumulatively, with controls for variations in treaty/ treaty type, except, importantly, in the case of the third hypothesis. For that hypothesis, all of the issue resolutions against the U.S. arose in claims under NAFTA and thus are specific to NAFTA; treaty/ treaty type was not a relevant variable.

Issue type. There were 14 coded issues in the study. The issues with the most resolutions were two jurisdictional issues (parallel claims and the concept of investment) and two substantive issues (content of fair and equitable treatment and of indirect/ regulatory expropriation). For these issues, expansive or restrictive resolutions arose in 40 to 50 cases per issue. The issues with the fewest resolutions, in 2 to 10 cases each, included three jurisdictional issues (natural person investor, permissibility of investment, and scope of umbrella clause) and a substantive issue (essential/ national security exception). 
Count of issues per case. The total number of issues that arose and were resolved expansively or responsively ranged from one to nine issues per case. The mean and median were four resolutions per case.

Total appointments per arbitrator. Individual arbitrators in the dataset were appointed between 1 and 14 times. The mean number of appointments was five and the median was three.

Case. There were 123 cases in which at least one issue was found to have been resolved expansively or restrictively.

Arbitrator. There were 204 individuals appointed as arbitrators in the 123 cases.

The dependent variable was the issue resolution. A total of 376 issues were coded as having been resolved expansively or restrictively across the 123 cases. This generated 1001 distinct instances in which an arbitrator resolved an issue. Of these, 736 resolutions were expansive and 265 were restrictive.

To examine the study's hypotheses, a generalized linear mixed effects model was used on the advice of a statistician, Heather Krause, who gave the (paraphrased) description of the statistical model that follows in the remainder of this paragraph. The model combined a linear mixed effects model and a general linear model. It is similar to a classical general linear model - the best known of which is logistic regression - with the addition of "random" effects to the "fixed" 
effects already dealt with in classical regression. A generalized linear mixed effects model is more flexible and allows for the adaptation of the model to the available data and its structure. For example, in the present study, the data was nested within both cases and arbitrators. Nested issues will not be independent of each other, requiring a model that controls for the resulting correlation. Random effects were used to account for this. As a general principle, a model should be as simple as possible while doing a good job of representing the data.

\section{A heading: Findings}

\section{B heading: Anticipated tendency in favour of claimants}

The first hypothesis predicted that arbitrators would tend to adopt an expansive approach for all of the coded issues combined. The results supported this expectation on a significant basis. Thus, there was a very low likelihood that the variation between expansive and restrictive resolutions among all of the coded issues was explained by chance. This made it safe to reject the null hypothesis that $50 \%$ of the resolutions would be expansive and $50 \%$ would be restrictive. ${ }^{53}$ Table one summarizes the variations in resolutions of all of the 14 issues.

\section{Table 1: Classification of Issue Resolutions by Issue ${ }^{54}$}

\footnotetext{
${ }^{53}$ The size of the effect was 0.3 , which is a strong effect for a one-sample binomial test.

${ }^{54}$ All figures are rounded to the nearest whole. There is a slight variation in the results, as previously reported in Van Harten, supra note 5, due to these data entry corrections to the originally reported data: issue 6 in Lauder $v$ Czech Republic was changed from expansive to non-classifiable for all three arbitrators; issue 3 in Joy Mining v
} 


\begin{tabular}{|c|c|c|c|}
\hline \multirow{2}{*}{ Issue } & \multirow{2}{*}{$\begin{array}{l}\text { No. of issue } \\
\text { resolutions }\end{array}$} & \multicolumn{2}{|c|}{ Resolution of issue } \\
\hline & & Expansive & Restrictive \\
\hline 1 - corporate person investor & 72 & $85 \%$ & $15 \%$ \\
\hline $2-$ natural person investor & 6 & $0 \%$ & $100 \%$ \\
\hline 3 - concept of investment & 119 & $70 \%$ & $30 \%$ \\
\hline 4 - minority shareholder interest & 75 & $92 \%$ & $8 \%$ \\
\hline 5 - permissibility of investment & 27 & $67 \%$ & $33 \%$ \\
\hline 6 - parallel claims & 162 & $84 \%$ & $16 \%$ \\
\hline 7 - scope of MFN treatment & 60 & $50 \%$ & $50 \%$ \\
\hline 8 - national treatment & 60 & $35 \%$ & $65 \%$ \\
\hline $\begin{array}{l}9 \text { - fair and equitable treatment } \\
\text { (autonomous standard) }\end{array}$ & 56 & $73 \%$ & $27 \%$ \\
\hline $\begin{array}{l}10-\text { fair and equitable treatment } \\
\text { (content) }\end{array}$ & 137 & $83 \%$ & $17 \%$ \\
\hline 11 - full protection and security & 51 & $57 \%$ & $43 \%$ \\
\hline 12 - indirect expropriation & 120 & $72.5 \%$ & $27.5 \%$ \\
\hline 13 - umbrella clause & 32 & $91 \%$ & $9 \%$ \\
\hline 14 - national security exception & 24 & $75 \%$ & $25 \%$ \\
\hline Cumulative & 1001 & $\mathbf{7 3 . 5} \%$ & $26.5 \%$ \\
\hline
\end{tabular}

Across all issues, expansive resolutions were about three times more common than restrictive resolutions. This varied modestly between jurisdictional issues (76\% expansive) and substantive issues (71\% expansive). The tendency in favor of an expansive approach was reflected in 11 of 14 issues, as Table one indicates. On the scope of MFN treatment, arbitrators were split and, on national treatment and natural person investor (albeit with very little data for this last issue), they

Egypt was changed from expansive to restrictive for all three arbitrators; issue 1 in Sedelmayer $v$ Russia was changed from restrictive to expansive for arbitrators Magnusson and Wachler (but not Zykin, whose resolution remained non-classifiable); issue 6 in Maffezini $v$ Spain was changed from restrictive to non-classifiable for all three arbitrators. 
tended toward a restrictive approach. The data was examined for whether the overall tendency varied over time. This revealed a greater tendency toward expansive resolutions over time, but without any statistically significant effect for the combined results or for the isolated results for either jurisdictional or substantive issues.

Thus, it is safe to say that the arbitrators favored an expansive approach overall. This supported the hypothesis that the arbitrators would resolve contested issues in ways that favoured prospective claimants. Tentatively, these results may be connected to the system's asymmetrical structure in the absence of institutional safeguards of independence. Depending on one's view of how the expansive and restrictive approaches were classified, the results may cause concern for those expecting the system to deliver evenness in the resolution of the coded issues. Respondent states clearly have lost across a range of issues that arise often in investment treaty arbitration. That said, the results do not explain fully or establish the truth of any expectation of bias. Also, the overall tendency did not apply to all issues. Finally, even for the issues that tended most often to be resolved expansively, some arbitrators took restrictive approaches. This demonstrates that other factors play a role in the exercise of interpretive discretion by arbitrators.

B heading: Anticipated tendency in favour of claimants from major Western capitalexporting states

The second hypothesis was that the tendency in favor of an expansive approach would be accentuated where the claimant was a national of France, Germany, the U.K., or the U.S as the main Western capital-exporters. Additional groupings associated with Western capital-exporting 
interests were also analysed. After accounting for the control variables in the model, a significant relationship was found between the dependent variable (issue resolutions) and all other variables operating simultaneously; i.e. the tendency toward expansive resolutions by arbitrators was very unlikely to be explained by chance. ${ }^{55}$ The data were also tested for effect sizes, indicating that the model explained $20 \%$ of the variation in issue resolutions as expansive or restrictive. ${ }^{56}$ This test estimates possible inaccuracies in the statistical model; it tends to underestimate rather than overestimate the strength of the association between issue resolutions and the predictor variables. ${ }^{57}$ In 1001 issue resolutions over 123 cases, there was evidence of a strong tendency in favour of an accentuated expansive approach if the claimant was a national of a major Western capital-exporting state. Based on the effect of the control variables, this was most apparent where the claim was brought under a BIT or the ECT, where it raised any of 9 of the coded issues, and - to a lesser extent and in the case of the jurisdictional issues only - where the issue was resolved by frequently-appointed arbitrators.

\footnotetext{
${ }^{55}$ The model generated an $\mathrm{F}(\mathrm{F}=11.72,23,150)$ that was significantly lower than the critical $\mathrm{F}$ value, with a $\mathrm{p}<.001$. [Note to editor: this need be included only if thought useful to append the technical table or online:] Table 7 outlines the results of the model and has been appended.

56 This was tested using the McFadden R-squared statistic: Cameron and F. Windmeijer, "An R-squared measure of goodness of fit for some common nonlinear regression models" (1997) 77(2) J Econometrics 329. This generated an effect size of .20 overall, indicating that the model explained $20 \%$ of the variation in issue resolutions as expansive or restrictive.

${ }^{57}$ [Note to editor: this need be included only if thought useful to append the technical table or online:] Table 8 outlines the change in the McFadden pseudo R-squared attributed to each individual predictor in the model and has been appended.
} 
The overall effect of the variable of primary interest - claimant nationality - for the main grouping (France, Germany, the U.K., and the U.S.) was significant $(\mathrm{F}=5.78,5,93 ; \mathrm{p}<.001)$. This supported the expectation that the claimants from these countries would benefit from an expansive resolution more often than other claimants. There was a significant likelihood in the case of both jurisdictional issues $(\mathrm{F}=5.78,5,93 ; \mathrm{p}<.001)$ and substantive issues $(\mathrm{F}=4.14,5,93$; $\mathrm{p}<=.01)$ that such claimants were more likely to benefit from an expansive resolution. [Note to editor: this table and figure provide details of the regression analysis. They are not necessarily required for the published article (perhaps working best as an appendix)]. Table 2 gives the $\log$ odds of each of the five categories of claimant nationality being resolved expansively with all other covariates held steady, highlighting that the findings for claimants from individual countries typically were not statistically significance because they carried a risk of error in excess of 5\%. Figure 1 presents the expected probability of an expansive resolution for each claimant nationality in grouping \# 1 with all other covariates held steady.

Table 2: Effect of claimant nationality (grouping \#1) on the likelihood of an expansive resolution

\begin{tabular}{|l|l|l|}
\hline Claimant nationality & Probability of expansive resolution & Statistical significance \\
\hline France & .66 & $\mathrm{p}=.34$ \\
\hline Germany & .54 & $\mathrm{p}=.85$ \\
\hline United Kingdom & .71 & $\mathrm{p}=.05$ \\
\hline United States & .66 & $\mathrm{p}=.04$ \\
\hline All others & .56 & $\mathrm{P}=.31$ \\
\hline
\end{tabular}


Figure 1: Probability of an expansive resolution by claimant nationality: overall (issues 1 to 14 )

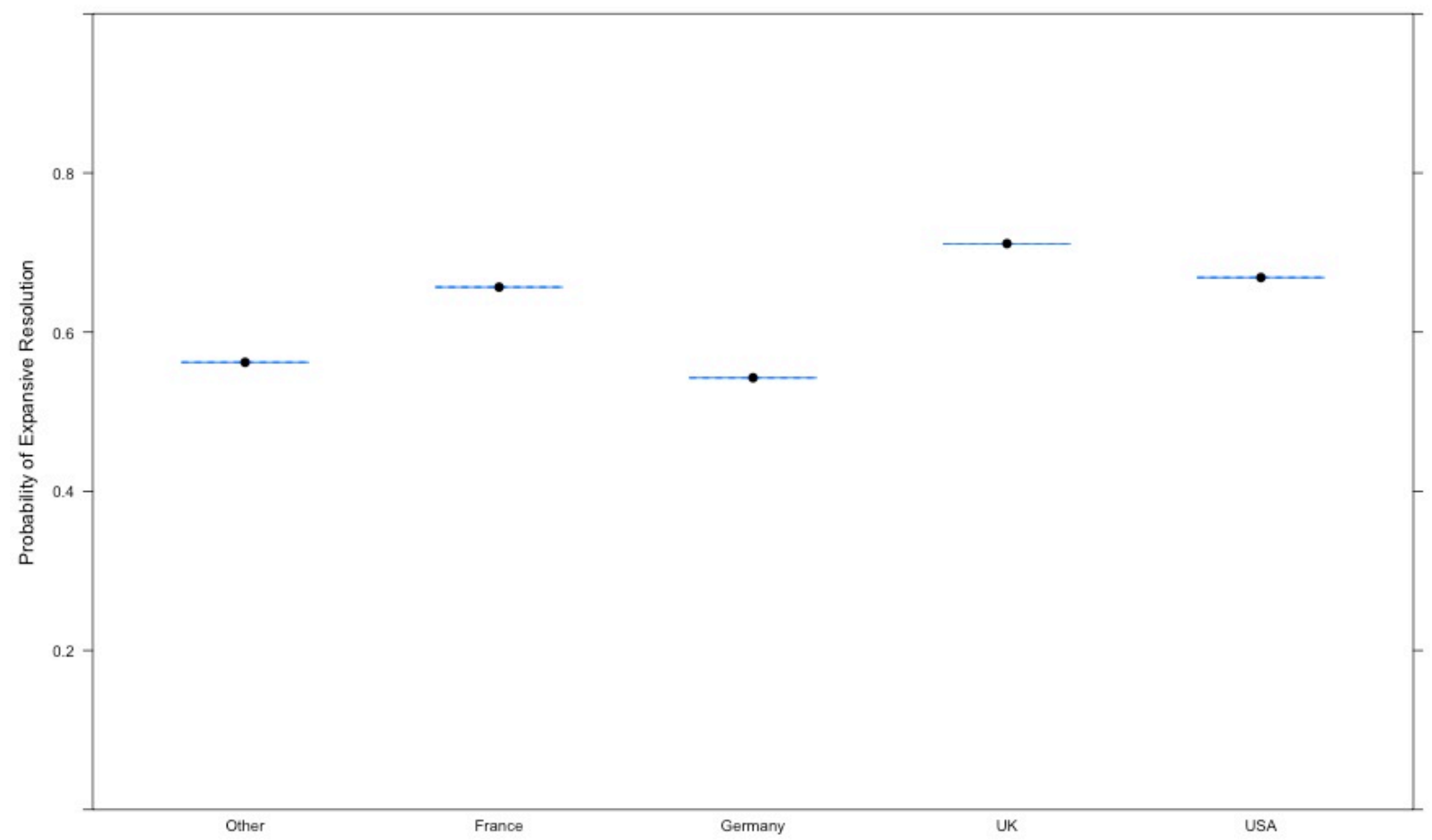

For jurisdictional and substantive issues, U.S. claimants benefited from an accentuated tendency toward expansive resolutions although they led the field only for jurisdictional issues. Thus, only the results for jurisdictional issues supported the more detailed expectation that U.S. claimants would enjoy the strongest accentuation of an expansive tendency. That said, country-by-country results had a higher risk of statistical error and were not always significant. For claimants from the U.K. and U.S., the country-specific results had a 5\% and 4\% risk of error; for claimants from Germany, France, and other states, the risk was $85 \%, 34 \%$, and $31 \%$ and thus not reliable. There was especially limited country-specific data for claimants of Germany and France; of 123 cases that generated the issue resolutions, 37 involved a U.S. claimant, 11 a U.K. claimant, 6 a French claimant, and 6 a German claimant. 
The findings were tested further by analysing other groupings of claimant nationalities associated with Western capital-exporting interests. The other groupings included the U.S. and U.K as a group; France, Germany, the U.K., and the U.S. cumulatively (i.e. combining all issue resolutions for claimants from these countries); G-7 states; Western European former colonial powers; OECD member states; and World Bank high income states. For each of these groupings, the findings supported the hypothesis and were statistically-significant. Similar tendencies were observed for other groupings (U.S. claimants alone; French, German, and U.K. claimants as a group; and UN geographic groupings) but the findings were not significant. Table 3 provides a detailed report.

Table 3: Analyses of additional groupings of claimant nationalities: overall (issues 1 to 14)

\begin{tabular}{|c|c|}
\hline Grouping & Summary of results \\
\hline $\begin{array}{l}\text { Grouping } \# 2 \\
\text { Group2A: United States }(n=359) \\
\text { Group2B: all other states }(n=642)\end{array}$ & $\begin{array}{l}\text { The grouping did not have an overall statistically-significant } \\
\text { effect }(\mathrm{F}=2.75,1,153, \mathrm{p}=.10) \text {. Claimants from the U.S. were } \\
63 \% \text { more likely to benefit from an expansive resolution than } \\
\text { claimants from all other states combined, but the effect was not } \\
\text { statistically significant because it carried a } 10 \% \text { risk that it was } \\
\text { explained by chance. }\end{array}$ \\
\hline $\begin{array}{l}\text { Grouping \#3 } \\
\text { Group 3A: France, Germany, and U.K. }(n=181) \\
\text { Group 3B: all other states (except U.S.) }(n=461)\end{array}$ & $\begin{array}{l}\text { The grouping did not have an overall statistically-significant } \\
\text { effect }(\mathrm{F}=3.47,1,153, \mathrm{p}=.07) \text {. Claimants from a state in group } \\
3 \mathrm{~A} \text { were } 52 \% \text { more likely to benefit from an expansive } \\
\text { resolution than claimants from all other states combined except } \\
\text { the U.S., but the effect was not statistically significant because }\end{array}$ \\
\hline
\end{tabular}




\begin{tabular}{|c|c|}
\hline & it carried a $7 \%$ risk that it was explained by chance. \\
\hline $\begin{array}{l}\text { Grouping \#4 } \\
\text { Group 4A: UK, US }(n=456) \\
\text { Group 4B: all other states }(n=545)\end{array}$ & $\begin{array}{l}\text { The grouping had an overall statistically-significant effect } \\
(\mathrm{F}=6.14,1,153, \mathrm{p}=.01) \text {. Claimants from the U.K. or the U.S. } \\
\text { were } 68 \% \text { more likely to benefit from an expansive resolution } \\
\text { than claimants from all other states combined. }\end{array}$ \\
\hline $\begin{array}{l}\text { Grouping } \# 5 \\
\text { Group 5A: France, Germany, U.K., and U.S. } \\
\text { cumulatively }(\mathrm{n}=558) \\
\text { Group 5B: all other states }(\mathrm{n}=443)\end{array}$ & $\begin{array}{l}\text { The grouping had an overall statistically-significant effect } \\
(\mathrm{F}=5.34,1,153, \mathrm{p}=.02) \text {. Claimants from a state in group } 5 \mathrm{~A} \\
\text { were } 67 \% \text { more likely to benefit from an expansive resolution } \\
\text { than claimants from all other states combined. }\end{array}$ \\
\hline $\begin{array}{l}\text { Grouping \#6 } \\
\text { Group 6A: historical G-7 states }(n=621) \\
\text { Group 6B: all other states }(n=380)\end{array}$ & $\begin{array}{l}\text { The grouping had an overall statistically-significant effect } \\
(\mathrm{F}=4.44,1,153, \mathrm{p}=.03) \text {. Claimants from a state in group } 6 \mathrm{~A} \\
\text { were } 46 \% \text { more likely to benefit from an expansive resolution } \\
\text { than claimants from all other states combined. Notably, there } \\
\text { were no cases in group } 6 \mathrm{~A} \text { involving a claimant from Japan. }\end{array}$ \\
\hline $\begin{array}{l}\text { Grouping \#7 } \\
\text { Group 7A: Western European former colonial } \\
\text { powers }(\mathrm{n}=187) \\
\text { Group 7B: all other states (except U.S.) }(\mathrm{n}=326)\end{array}$ & $\begin{array}{l}\text { The grouping had an overall statistically-significant effect } \\
(\mathrm{F}=7.22,1,153, \mathrm{p}=.01) \text {. Claimants from a state in group } 7 \mathrm{~A} \\
\text { were } 48 \% \text { more likely to benefit from an expansive resolution } \\
\text { than claimants from all other states combined except the U.S. }\end{array}$ \\
\hline $\begin{array}{l}\text { Grouping \#8 } \\
\text { Group 8A: States in North America, Western } \\
\text { Europe, Southern Europe, and Northern Europe } \\
(\mathrm{n}=849) \\
\text { Group 8B: all other states }(\mathrm{n}=152)\end{array}$ & $\begin{array}{l}\text { The grouping did not have an overall statistically-significant } \\
\text { effect }(\mathrm{F}=2.81,1,153, \mathrm{p}=.10) \text {. Claimants from states in group } \\
8 \mathrm{~A} \text { were } 31 \% \text { more likely to benefit from an expansive } \\
\text { resolution than claimants from all other states combined, but } \\
\text { the effect was not statistically-significant because it carried a } \\
10 \% \text { risk that it was explained by chance. As a descriptive } \\
\text { finding, } 85 \% \text { of issue resolutions were in cases brought by a } \\
\text { claimant from a state in group } 8 \mathrm{~A} \text {. }\end{array}$ \\
\hline $\begin{array}{l}\text { Grouping } \# 9 \\
\text { Group 9A: States in Eastern Europe }(n=5)\end{array}$ & $\begin{array}{l}\text { The grouping could not be tested because there were only five } \\
\text { cases, in group 9A, brought by Eastern European claimants. }\end{array}$ \\
\hline
\end{tabular}




\begin{tabular}{|c|c|}
\hline $\begin{array}{l}\text { Group 9B: all others (except states in North } \\
\text { America, Western Europe, Southern Europe, and } \\
\text { Northern Europe) }\end{array}$ & \\
\hline $\begin{array}{l}\text { Grouping } \# 10 \\
\text { Group 10A: OECD members as of } 1990(n=490) \\
\text { Group 10B: all other states }(n=511)\end{array}$ & $\begin{array}{l}\text { The grouping had an overall statistically-significant effect } \\
(\mathrm{F}=6.41,1,153, \mathrm{p}=.01) \text {. Claimants from states in group } 10 \mathrm{~A} \\
\text { were } 31 \% \text { more likely to benefit from an expansive resolution } \\
\text { than claimants from all other states combined. }\end{array}$ \\
\hline $\begin{array}{l}\text { Grouping \#11 } \\
\text { Group 11A: OECD members as of } 2000(n=755) \\
\text { Group 11B: all others }(n=246)\end{array}$ & $\begin{array}{l}\text { The grouping had an overall statistically-significant effect } \\
(\mathrm{F}=12.42,1,153, \mathrm{p}=.005) \text {. Claimants from states in group 11A } \\
\text { were } 27 \% \text { more likely to benefit from an expansive resolution } \\
\text { than claimants from all other states combined. }\end{array}$ \\
\hline $\begin{array}{l}\text { Group \#12 } \\
\text { Group 12A: High income states as of } 1990 \\
(\mathrm{n}=813) \\
\text { Group 12B: all other states }(\mathrm{n}=188)\end{array}$ & $\begin{array}{l}\text { The grouping had an overall statistically-significant effect } \\
(\mathrm{F}=7.04,1,153, \mathrm{p}=.008) \text {. Claimants from states in group } 12 \mathrm{~A} \\
\text { were } 23 \% \text { more likely to benefit from an expansive resolution } \\
\text { than claimants from all other states combined. As a descriptive } \\
\text { finding, } 81 \% \text { of issues resolutions were in cases brought by a } \\
\text { claimant from a state in group 12A. }\end{array}$ \\
\hline $\begin{array}{l}\text { Group \#13 } \\
\text { Group 13A: High income states as of } 2000 \\
(n=828) \\
\text { Group 13B: All other }(n=173)\end{array}$ & $\begin{array}{l}\text { The grouping had an overall statistically-significant effect } \\
(\mathrm{F}=6.18,1,153, \mathrm{p}=.01) \text {. Claimants from states in group } 13 \mathrm{~A} \\
\text { were } 22 \% \text { more likely to benefit from an expansive resolution } \\
\text { than claimants from all other states combined. As a descriptive } \\
\text { finding, } 83 \% \text { of issues resolutions were in cases brought by a } \\
\text { claimant from a state in group 13A. }\end{array}$ \\
\hline
\end{tabular}

The model controlled for other effects and there was sufficient data to provide some findings that involve the effect of other factors on the tendency toward an expansive approach and that are incidental to the original hypotheses of the study. Perhaps most importantly, it was found that the 
variable of the specific issue - among the 14 coded issues - accounted significantly for about $8 \%$ of the overall variation in issue resolutions ( $\mathrm{F}=39.87,13,208, \mathrm{p}<.001)$. This finding highlighted the importance of focusing on those issues for which there was extensive data in any comparison of issue-by-issue results. Figure 2 outlines the issue-by-issue coding results across the 1001 issue resolutions.

Figure 2: Breakdown of issue resolutions by specific issue

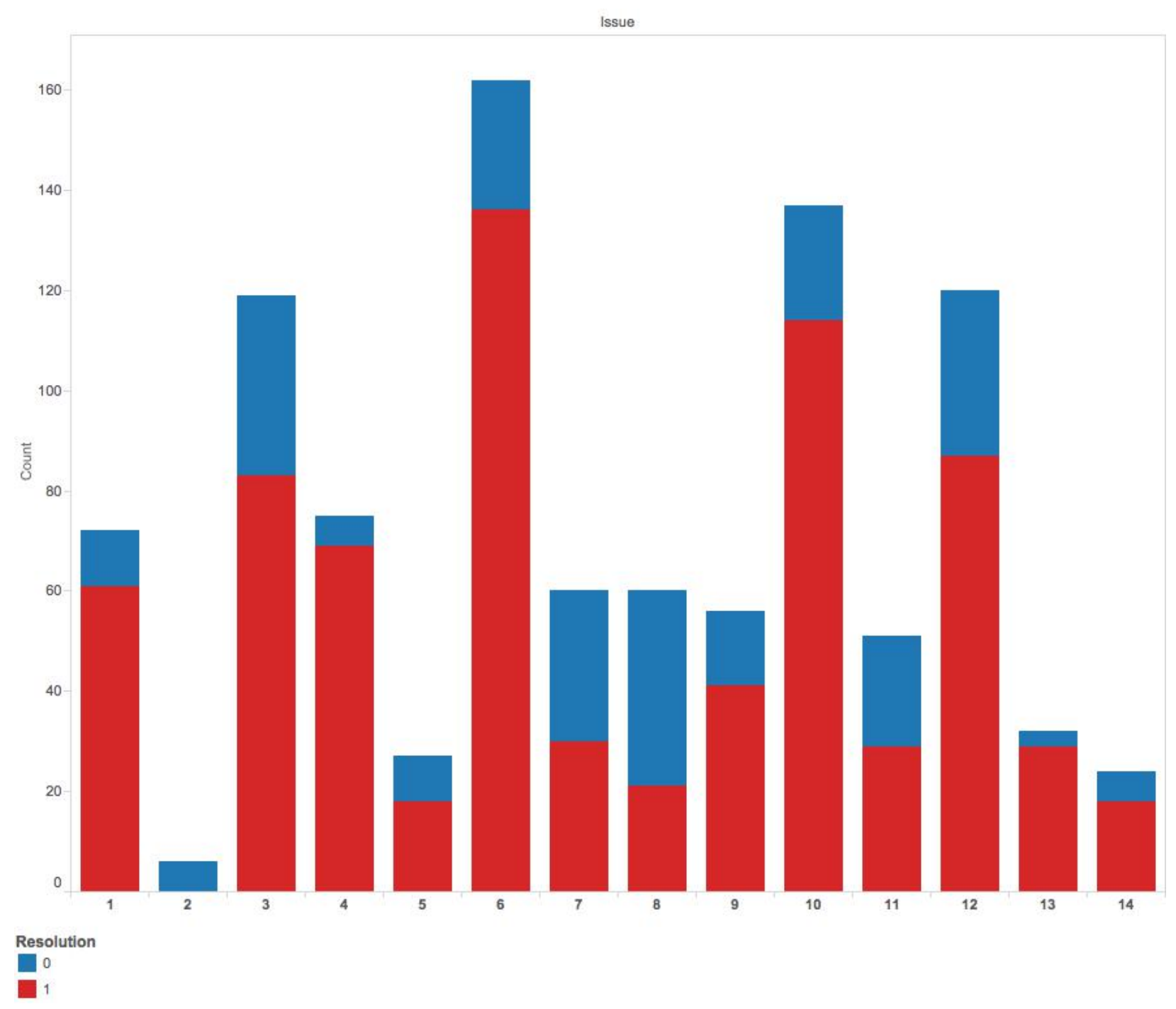


Importantly, these issue-by-issue results are only descriptive; the predictive analysis in the model focused on the overall tendency in the resolution of all 14 issues combined.

The statistical analysis also revealed incidentally that variations in issue resolutions among the three main treaties or treaty types (BITs, the ECT, and NAFTA) had a significant effect on variations in the issue resolutions overall $(\mathrm{F}=10.17,4,103, \mathrm{p}<.001)$, with an effect size of $6 \%$ ( $7 \%$ for jurisdictional issues, though only $2 \%$ for substantive issues). Issues arising and resolved under NAFTA had the lowest likelihood of being resolved expansively and there were no noteworthy difference between BITs and the ECT. Table 4 indicates the probabilities for each treaty/ treaty type across the 14 issues, controlling for all other variables. Again, these are descriptive findings; they explain what happened based on the coded data and should not be taken to predict reliably what will happen in the future.

Table 4: Effects of Treaty/ Treaty Type on the Likelihood of an Expansive Resolution

\begin{tabular}{|l|l|l|}
\hline Treaty/ treaty type & Probability & p-value \\
\hline Bilateral investment treaty (BIT) & .67 & .001 \\
\hline Energy Charter Treaty (ECT) & .75 & .001 \\
\hline $\begin{array}{l}\text { North American Free Trade } \\
\text { Agreement (NAFTA) }\end{array}$ & .54 & .03 \\
\hline
\end{tabular}


Perhaps less importantly, the model indicated incidentally that, as total issue resolutions increased per case, so too did the likelihood that the issues would be resolved expansively. However, the effect size of $3 \%$ for this variable was relatively small, indicating that this was not important by itself as a predictor of issue resolutions. It was also found that the frequency of arbitrator appointments (measured by the total count of appointments per arbitrator) was a significant factor for jurisdictional issues and cumulatively, but with a relatively small effect size ( $3 \%$ and $2 \%$, respectively). For the substantive issues, this factor did not have a significant effect.

These findings supported the expectation that arbitrators would resolve issues differently for foreign investors that are associated with a major Western capital-exporter. Overall and for both jurisdictional and substantive issues, all of the groupings indicated a tendency toward expansive resolutions for these claimants. The strongest finding was that claimants from those states when they bring claims under a BIT or the ECT and raise any of 11 of the coded issues - are more likely to benefit from an expansive approach. By extension, respondent states are at a disadvantage relative to claimants overall but are more likely to benefit from a restrictive approach when the claimant is from a state other than a major Western capital-exporter, especially if the claim is brought under NAFTA.

What should one make of these results? They may be surprising if one anticipated that the resolution of contested legal issues would not vary much according to claimant nationality. Indeed, this seems to be a basic proposition of impartiality in international adjudication. However, there are also limitations in the case of observed tendencies at a systemic level. While 
arbitrator incentives provided the rationales for the study's hypotheses, they should not be taken to explain the results fully. Other possible explanations that were not tested here could include variations in ideological preferences of arbitrators; variations in parties' legal representation; poor appointment decisions by groups of states or investors; or variations in the degree to which some cases may influence subsequent interpretations. ${ }^{58}$ The findings are tentative for these and other reasons. Even so, whatever the explanation for the results, the observed tendencies raise questions about the fairness of investment treaty arbitration for interests that are not associated with major Western capital-exporters. They indicate that suspicions of bias about the system do have a systemic basis that is linked to the arbitrators' exercise of discretion.

B heading: Anticipated systemic bias in favour of the U.S.

It was hypothesized that the tendency in favor of an expansive approach would be lessened where the respondent was France, Germany, the U.K., or the U.S. However, it emerged that the U.S. was the only country for which there was data on this issue; that is; among the four countries initially identified to represent major Western capital-exporting states, only the U.S. was subject to a decision in which the arbitrators resolved coded issues. France, Germany, and the U.K. had not been the subject of such decisions presumably because, unlike the U.S., they had (and have) not consented to investor-state arbitration in a broad-based investment treaty with

\footnotetext{
${ }^{58}$ Sisk and Heise, supra note 15 at 746; R. Polk Wagner and L. Petherbridge, "Is the Federal Circuit Succeeding? An Empirical Assessment of Judicial Performance" (2004) 152 U Pa L Rev 1105 at 1129; C. A Rogers, "The Arrival of the "Have-Nots" in International Arbitration" (2007) 8 Nev LJ 341 at 357-358; O. K. Fauchald, "The Legal Reasoning of ICSID Tribunals - An Empirical Analysis” (2008) 19 EJIL 301 at 337-338.
} 
another developed state. A few cases against France or Germany under the ECT came after the cut-off dates for the study. As well, all of the cases against the U.S. were brought by Canadian investors under NAFTA. Thus, while there was sufficient data for reliable findings, the more limited dataset makes the findings for this hypothesis less robust than the findings for the first two hypotheses.

For example, due to limited data, it was not possible to test this hypothesis for jurisdictional or substantive issues alone. It was also not possible to isolate other potential effects built into the model in order to generate incidental findings, as was done for the hypothesis related to claimant nationality. That said, the results indicated that the U.S. was more likely than other countries to benefit from a restrictive approach, when other variables were held steady. On a statisticallysignificant basis, the U.S. benefited from a restrictive approach:

- $60 \%$ more often than the other 45 respondent states under BITs and the ECT.

- $55 \%$ more often than Canada under NAFTA.

- $35 \%$ more often than Canada and Mexico, under NAFTA and in one BIT case.

- $35 \%$ more often than non-high income respondent states, ${ }^{59}$ usually under BITs and the ECT.

- $37 \%$ more often than other OECD states. ${ }^{60}$

- $59 \%$ more often than all states other than the Western European former colonial powers. $^{61}$

\footnotetext{
${ }^{59}$ i.e. states not listed supra notes 41-42.

${ }^{60}$ i.e. states listed supra notes 39-40.
} 
Table 5 outlines the findings in more detail, comparing the U.S. alone, as a respondent state, to the other groupings of respondents states not associated with major Western capital-exporters. Because the data for the U.S. arose from its experience as a respondent state under NAFTA, groupings involving the other NAFTA respondent states - Canada and Mexico - were also examined.

Table 5: Analyses of groupings of respondents: overall (issues 1 to 14 )

\begin{tabular}{|c|c|}
\hline Grouping & Summary of results \\
\hline $\begin{array}{l}\text { Grouping \#1 } \\
\text { Group 1A: United States }(n=45) \\
\text { Group 1B: all others }(n=956)\end{array}$ & $\begin{array}{l}\text { This grouping had an overall statistically-significant effect } \\
(\mathrm{F}=21.65,1,153, \mathrm{p}<.01) \text {. As a respondent, the U.S. was } 60 \% \\
\text { more likely to benefit from a restrictive resolution than all other } \\
\text { states. }\end{array}$ \\
\hline $\begin{array}{l}\text { Grouping \#2 } \\
\text { Group2A: United States }(n=45) \\
\text { Group2B: Canada }(n=32)\end{array}$ & $\begin{array}{l}\text { The grouping had an overall statistically-significant effect } \\
(\mathrm{F}=23.16,1,153, \mathrm{p}<.01) \text {. The U.S. was } 55 \% \text { more likely to } \\
\text { benefit from a restrictive resolution than Canada. }\end{array}$ \\
\hline $\begin{array}{l}\text { Grouping \#3 } \\
\text { Group 3A: United States }(n=45) \\
\text { Group 3B: Canada and Mexico }(n=89)\end{array}$ & $\begin{array}{l}\text { The grouping had an overall statistically-significant effect } \\
(\mathrm{F}=20.81,1,153, \mathrm{p}=.04) \text {. The U.S. was } 35 \% \text { more likely to } \\
\text { benefit from a restrictive resolution than Canada and Mexico. }\end{array}$ \\
\hline $\begin{array}{l}\text { Grouping \#4 } \\
\text { Group 4A: United States }(n=45)\end{array}$ & $\begin{array}{l}\text { The grouping had an overall statistically-significant effect } \\
(\mathrm{F}=17.47,1,153, \mathrm{p}<.01) \text {. The U.S. was } 35 \% \text { more likely to }\end{array}$ \\
\hline
\end{tabular}

\footnotetext{
${ }^{61}$ i.e. states not listed supra note 36.
} 


\begin{tabular}{|c|c|}
\hline $\begin{array}{l}\text { Group 4B: all other states except high income } \\
\text { states as of } 1990 \text { and } 2000(n=891)\end{array}$ & $\begin{array}{l}\text { benefit from a restrictive resolution than non-high income } \\
\text { states. }\end{array}$ \\
\hline $\begin{array}{l}\text { Grouping \#5 } \\
\text { Group 5A: United States }(n=45) \\
\text { Group 5B: all other OECD states as of } 1990 \\
(n=41)\end{array}$ & $\begin{array}{l}\text { The grouping did not have an overall statistically-significant } \\
\text { effect ( } \mathrm{F}=0.14,1,153, \mathrm{p}=.89 \text { ). The U.S. was } 65 \% \text { more likely } \\
\text { to benefit from a restrictive resolution than other OECD states } \\
\text { as of } 1990 \text {, but the effect was not statistically-significant } \\
\text { because it carried an } 89 \% \text { risk that it was explained by chance. }\end{array}$ \\
\hline $\begin{array}{l}\text { Grouping } \# 6 \\
\text { Group 6A: United States }(n=45) \\
\text { Group 6B: all other OECD states as of } 2000 \\
(n=194)\end{array}$ & $\begin{array}{l}\text { The grouping had an overall statistically-significant effect } \\
(\mathrm{F}=17.03,1,153, \mathrm{p}=.02) \text {. The U.S. was } 37 \% \text { more likely to } \\
\text { benefit from a restrictive resolution than other OECD states as } \\
\text { of } 2000 \text {. }\end{array}$ \\
\hline $\begin{array}{l}\text { Grouping \#7 } \\
\text { Group 7A: United States }(\mathrm{n}=45) \\
\text { Group 7B: all other states except Western } \\
\text { European former colonial powers }(\mathrm{n}=926)\end{array}$ & $\begin{array}{l}\text { The grouping had an overall statistically-significant effect } \\
(\mathrm{F}=21.96,1,153, \mathrm{p}<.01) \text {. The U.S. was } 59 \% \text { more likely to } \\
\text { benefit from a restrictive resolution than other states besides the } \\
\text { former Western European colonial powers. }\end{array}$ \\
\hline
\end{tabular}

Taken together, these findings support the original hypothesis that the U.S, as a major Western capital exporter, would receive more favourable treatment in the resolution of contested legal issues. The findings are limited to the U.S. and did not test the expectation for other countries on any statistical basis. Also, the findings emerged only from the U.S. experience as a respondent exclusively under NAFTA, meaning that they could be explained by an overall more restrictive approach by NAFTA arbitrators as compared to BIT and ECT arbitrators. However, this 
explanation is contradicted by the finding that the U.S. benefited from restrictive resolutions significantly more than Canada, which was also a respondent state only under NAFTA, and Mexico, which was a respondent under NAFTA in all but one of the coded cases. Further, the coded issues reflected a range (nine) of the 14 issues that were coded, and those issues arise often at a general level across the treaties and treaty types beyond NAFTA.

In the findings for the different groupings of respondent states, compared to the U.S., the higher likelihood of a restrictive resolution in cases against the U.S. ranged from 35 to $60 \%$. As an aside, this variation was less stark than what one sees in the raw coding results, which indicated a much higher likelihood of restrictive resolutions in favour of the U.S. The different between the statistical findings and the raw results highlights the role of the control variables. By holding such variable steady, the apparent benefit enjoyed by the U.S. was diminished but still significant. Similarly, if they are viewed by themselves, the raw results would exaggerate the evidence of a pro-U.S. bias. With that caveat in mind, I have reproduced the raw results below to shed greater light on the ways in which the U.S. was found to benefit more often from a restrictive approach.

These raw results can be summarized as follows. The 14 coded issues were resolved expansively 6 times and restrictively 39 times in cases against the U.S. In NAFTA cases against Canada and Mexico, the respective ratios were 24 to 8 and 34 to 14 . In cases against all other respondent states under all treaties and treaty types, the proportion was 730 expansive to 216 restrictive. Thus, the proportion of expansive resolutions was $13 \%$ for the U.S. in contrast $75 \%$ for Canada, 
$71 \%$ for Mexico, and $77 \%$ for all other states. Figures 3 and 4 represent these descriptive findings about the raw results.

Figure 3: Issue resolutions per arbitrator, by respondent state

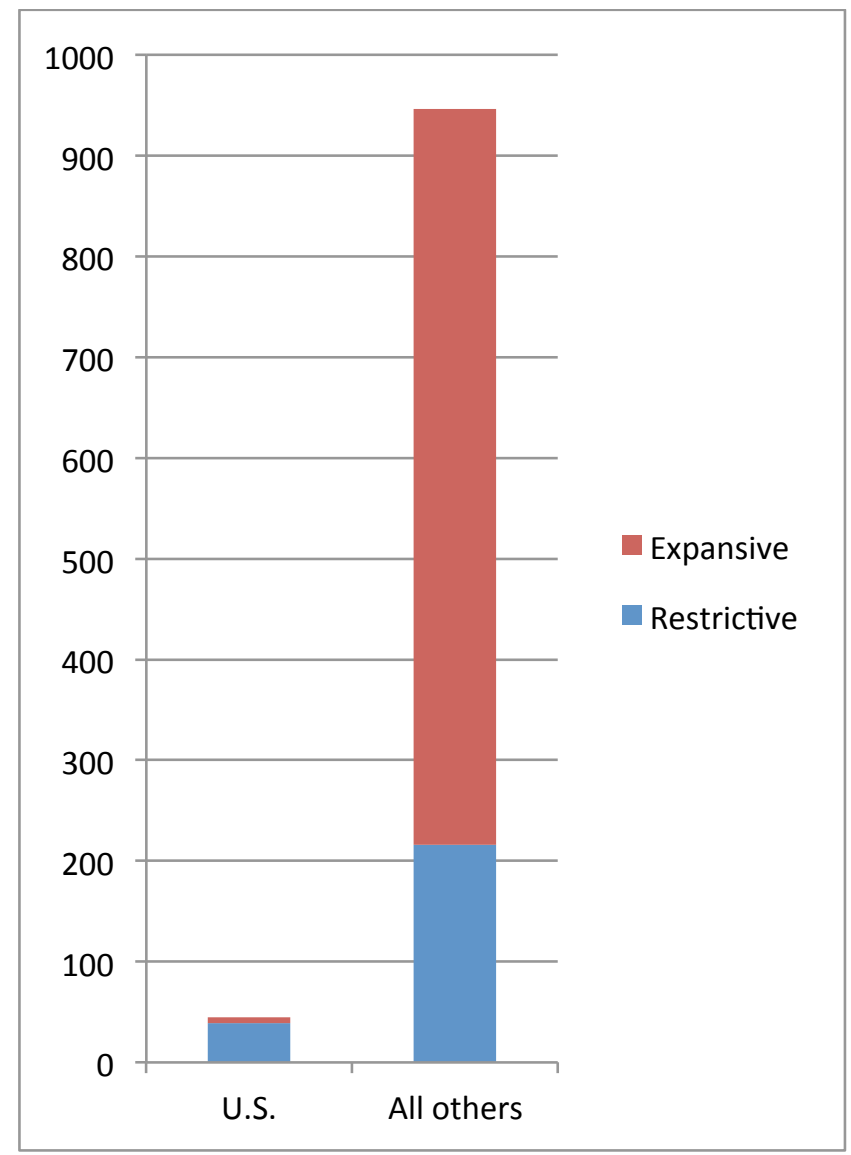

Figure 4: Issue resolutions per arbitrator under NAFTA, by respondent state 


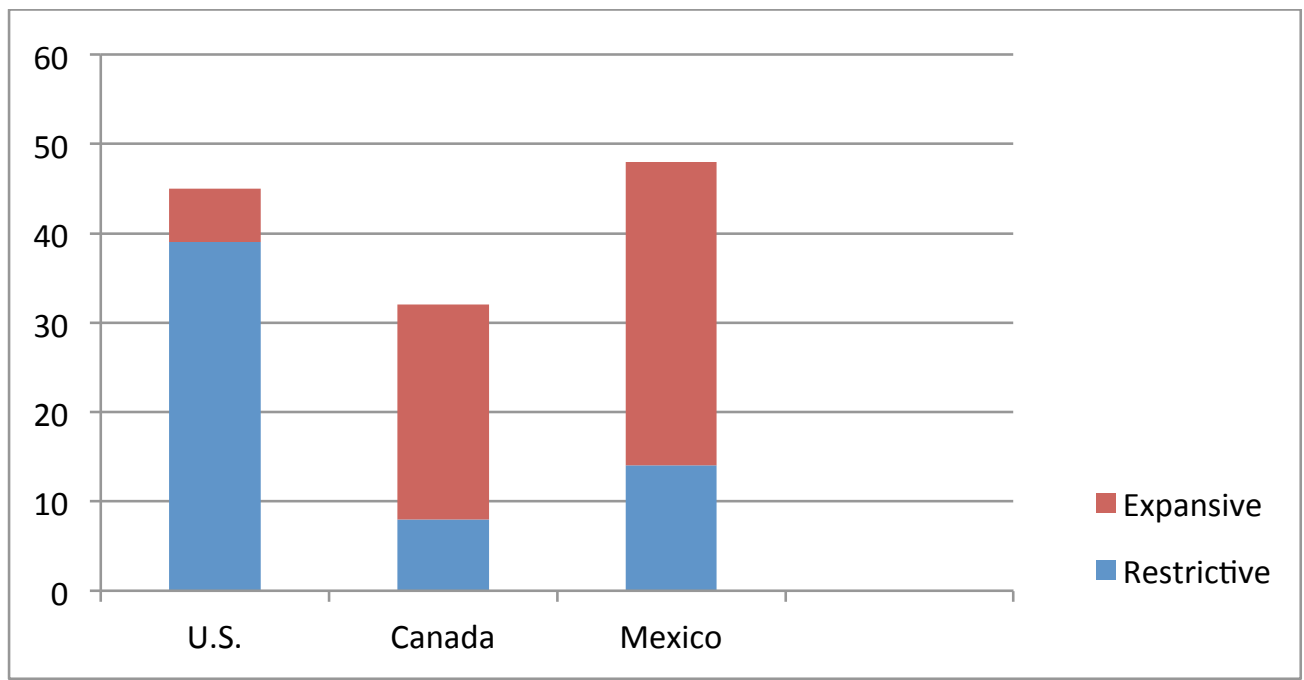

As a further illustration of the raw results, table 6 outlines the issue resolutions in NAFTA cases against Canada, Mexico, and the U.S. I have reported the information in this table to provide more background to those who are familiar with the doctrine of NAFTA investment law and interested to know how the issue resolutions in the coded data were distributed by issue and respondent state. Again, I stress that these are not reliable predictive findings because they are not based on the statistical model which held control variables steady. They do not impact on the overall finding of pro-U.S. bias outlined above, except to demonstrate how the tendency was based on data drawn from, for example, a range of issues under the same treaty. The following is simply a report of the raw coding, for transparency.

Table 6: Raw coding results for all issue resolutions under NAFTA

\begin{tabular}{|l|l|l|l|}
\hline & Canada & Mexico & United States \\
\hline
\end{tabular}




\begin{tabular}{|l|l|l|l|}
\hline Issue 1: corporate person investor & & 6 expansive $^{62}$ & 3 restrictive $^{63}$ \\
\hline Issue 2: natural person investor & & & 3 restrictive $^{64}$ \\
\hline Issue 3: concept of investment & 6 expansive $^{65}$ & 3 restrictive $^{66}$ & 6 restrictive $^{67}$ \\
\hline Issue 4: minority shareholder interests & & 6 expansive $^{68}$ & \\
& & & \\
\hline
\end{tabular}

${ }^{62}$ Waste Management Inc v United Mexican States (No 2) (30 April 2004) 43 ILM 967 at paras. 76-77 and 85; Fireman's Fund Insurance Company v United Mexican States (17 July 2003), 15(6) World Trade and Arb Mat 3 at para. 5; Fireman's Fund Insurance Company v United Mexican States (17 July 2006), ICSID Case No $\mathrm{ARB}(\mathrm{AF}) / 02 / 01$ at paras. $137-138$.

${ }^{63}$ Loewen Group, Inc and Raymond L Loewen v United States of America (26 June 2003) 42 ILM 811 at paras. 220239.

${ }^{64}$ ibid.

${ }^{65}$ Pope \& Talbot Inc v Government of Canada (26 June 2000, UNCITRAL Rules) at para. 96; SD Myers, Inc v Government of Canada (12 November 2000) 40 ILM 1408 at paras. 226-231 (majority opinion) and 39-41

(Schwartz separate opinion).

${ }^{66}$ Bayview Irrigation District et al v United Mexican States (19 June 2007) 19(5) World Trade and Arb Mat 5 at paras. 91 and 98-105.

${ }^{67}$ Methanex Corporation v United States of America (3 August 2005) 44 ILM 1345 at paras. IV.D.16-IV.D.18; Canadian Cattleman for Fair Trade v United States of America (28 January 2008, UNCITRAL Rules) at paras. 111112 and 193.

${ }^{68}$ GAMI Investments, Inc v Government of the United Mexican States (15 November 2004) 44 ILM 545, [26]-[35]; International Thunderbird Gaming Corporation v United Mexican States (26 January 2006) 18(2) World Trade and Arb Mat 59 at paras. 97-110. 


\begin{tabular}{|l|l|l|l|}
\hline Issue 6: parallel claims & & 3 expansive $^{69}$ & 3 restrictive $^{70}$ \\
\hline Issue 8: national treatment & 6 expansive $^{71}$ & $\begin{array}{l}1 \text { expansive }^{73} \\
6 \text { restrictive }^{74}\end{array}$ & 9 restrictive $^{75}$ \\
\hline Issue 9: fair \& equitable treatment (autonomous standard) & 3 expansive $^{76}$ & & 3 restrictive $^{77}$ \\
\hline Issue 10: fair \& equitable treatment (content) & 6 expansive $^{78}$ & 6 expansive $^{79}$ & 6 expansive $^{81}$ \\
\hline
\end{tabular}

${ }^{69}$ GAMI, supra note 58 at paras. 24-42.

${ }^{70}$ Loewen, supra note 53 at paras. 143, 149, and 154.

${ }^{71}$ Pope \& Talbot Inc v Government of Canada (10 April 2001), 13(4) World Trade and Arb Mat 61 at paras. 76-78; SD Myers, supra note 55 at paras. 250-255 (majority opinion); United Parcel Service of America, Inc v Government of Canada (24 May 2007, UNCITRAL Rules) at paras. 17, 94-96, and 101-102 (majority opinion).

${ }^{72}$ Merrill \& Ring Forestry LP v Government of Canada (31 March 2010, UNCITRAL Rules) at paras. 83 and 8793; United Parcel Service, supra note 71 at paras. 98-101, 117, 135-136, and 174-178 (majority opinion).

${ }^{73}$ International Thunderbird, supra note 58 at paras. 2-4 (Walde separate opinion).

${ }^{74}$ GAMI, supra note 58 at paras. 112 and 114-115; Feldman Karpa (Marvin Roy) v United Mexican States (16 December 2002) 42 ILM 625 at pages 6-9 and 15 (Blanco separate opinion); International Thunderbird, supra note 58 at paras. $180-183$ (majority opinion).

${ }^{75}$ ADF Group Inc v United States of America (9 January 2003), 15(3) World Trade and Arb Mat 55 at paras. 157158; Loewen, supra note 53 at paras. 139-140; Methanex, supra note 67 at paras. IV.B.12-IV.B.29.

${ }^{76}$ Pope \& Talbot, supra note 71 at paras. 108-118.

${ }^{77} \mathrm{ADF}$, supra note 75 at para. 183.

${ }^{78}$ Pope \& Talbot, supra note 71 at paras. 116 and 118; SD Myers, supra note 55 at paras. 263 and 266-268 (majority opinion) and 233 (Schwartz separate opinion).

${ }^{79}$ GAMI, supra note 58 at paras. 103-104 and 107-110; Metalclad Corporation v United Mexican States (30 August 2000) 40 ILM 36 at paras. 89 and 97-101. 


\begin{tabular}{|l|l|l|l|}
\hline & & 5 restrictive $^{80}$ & 6 restrictive $^{82}$ \\
\hline Issue 12: indirect/ regulatory expropriation & 3 expansive $^{83}$ & 12 expansive $^{85}$ & 6 restrictive $^{86}$ \\
& 3 restrictive $^{84}$ & & \\
\hline
\end{tabular}

Based on the statistical findings for this hypothesis, it appears that aspects of investment treaty law that may give rise to substantial state liability have been applied less rigorously to the U.S. than to the other NAFTA states under NAFTA and, although the comparison is less direct because it involves treaties other than NAFTA, to other respondent states. There was no basis to evaluate whether this pro-U.S. tendency extended to other major Western capital-exporters.

However, the pro-U.S. variation in the case of NAFTA claims by Canadian investors against the

${ }^{81} \mathrm{ADF}$, supra note 75 at para. 188; Mondev International Ltd $v$ United States of America (11 October 2002) 42 ILM 85 at paras. $113-127$.

${ }^{80}$ Waste Management (No 2), supra note 52 at paras. $92-93$ and 98-101; International Thunderbird, supra note 58 at paras. 194-201 (majority opinion).

${ }^{82}$ Loewen, supra note 53 at paras. 132-137; Methanex, supra note 67 at paras. IV.C.14-IV.C.25.

${ }^{83}$ Pope \& Talbot, supra note 65 at paras. 96 and 101-102.

${ }^{84}$ SD Myers, supra note 55 at paras. 281 and 287 (majority opinion) and 220-223 (Schwartz separate opinion).

${ }^{85}$ Feldman, supra note 64 at paras. 100-111 and 128-129; Waste Management (No 2), supra note 52 at paras. 143, 155, 160-162, and 171-177; Archer Daniels Midland Company and Tate \& Lyle Ingredients Americas, Inc v The United Mexican States (21 November 2007) 146 ILR 439 at paras. 240-248; Metalclad, supra note 79 at paras. 107 and 111-112.

${ }^{86}$ Methanex, supra note 67 at para. IV.D.7; Glamis Gold Ltd v United States of America (8 June 2009) 48 ILM 1035 at paras. 354-357 and 536 . 
U.S., and in favour of U.S. investors that brought NAFTA or BIT against other states, suggests tentatively that there is a degree of hierarchy among Western capital-exporters themselves.

Reflecting on the original theoretical rationales for the hypotheses for the study, the findings provide support for the hypothesis of systemic pro-U.S. bias based on the disproportionate power of the U.S. over the economic position of arbitrators and the arbitration industry. They also provide support for the expectation that U.S. power in the organizations that exercise default appointing authority, and in the negotiation of investment treaties, would affect how arbitrators exercise their discretionary power. They also appear relevant to the widely-known contextual fact, regarding case outcomes, that the U.S. has never lost a NAFTA case. That is, if the arbitrators tend to apply the same disciplines more softly to the U.S. than to other states, it is less surprising that the U.S. rarely (or never) loses cases. However, I stress that, like other findings in this study, the results may be explained by a range of alternative explanations such as a superior legal capacity of the U.S. government or ideological preferences of the arbitrators.

\section{A heading: Conclusion}

The present study was an attempt to use empirical methods to test specific hypotheses of systemic bias arising from larger institutional concerns. It relied on a content analysis of arbitrators' resolutions of contested legal issues instead of other empirical approaches and so offers only one perspective, derived from a particular method. In turn, its findings should be taken as tentative. 
However, it was somewhat eye-opening to find strong support for the anticipated tendency toward an expansive (pro-claimant) approach and, more so, for the expected accentuation of this tendency in the case of claimants from the four major Western capital- exporting states. The finding of significant support for the expected reduced tendency in cases against the U.S. was also eye-opening, though it was less robust because it was based on a smaller amount of data and thus more limited to the sample of data that was coded and analyzed.

To put this point in other words, the findings of (a) apparent systemic bias in favour of the U.S. as a respondent state were limited to the cumulative results under NAFTA and, primarily to the U.S.-Canadian investor relationship, and thus were less robust than those of (b) apparent systemic bias in favour of claimants from the U.S., U.K., France, and Germany across jurisdictional and substantive issues both in isolation and cumulatively. Both sets of findings were supported incidentally by analyses of other groupings of comparable states, such as G-7 states, Western European former colonial powers, and OECD members (to represent Western capital-exporting states) and the opposites of these three categories to represent other states in the world.

The study is subject to important limitations that I have summarized in the introduction and text of this article, and elaborated previously ${ }^{87}$ Briefly, empirical research cannot resolve issues of possible bias in any particular case. At the systemic level, an empirical project should be understood as an attempt to falsify discrete expectations (i.e. that arbitrators in general would be influenced by their unique and apparent dependencies on prospective claimants and powerful

\footnotetext{
${ }^{87}$ Van Harten, supra note 5 at 231-3.
} 
states) not to prove or disprove possible bias. ${ }^{88}$ This study is not, nor is there likely ever to be, a final word on whether there is bias in the system. ${ }^{89}$

Keeping the limitations in mind, the findings provide a perspective on how arbitrators are able to, and may in fact, shift the rules according to who is suing whom and may even be incented to do this as a result of their unique status compared to other adjudicators who decide similar types of disputes. The author's view based on this study is that there is only very tentative evidence of the expectations of systemic bias at present, but that this supports the well-established doctrinal and theoretical rationales for using institutional safeguards of judicial independence - including secure tenure, a set amount of remuneration not dependent on the length or frequency of cases, objective methods of case assignment, and prohibitions on issue conflicts and outside counsel work - to reduce the risk of actual and perceived bias in adjudication. Such safeguards would help to ensure that states, investors, and other affected actors do not have a reasonable basis to worry about potential bias.

\footnotetext{
${ }^{88}$ R. Lempert, "Empirical Research for Public Policy: With Examples from Family Law" (2008) 5 J Empirical Legal Studies 907 at 916.

${ }^{89}$ Sisk and Heise, supra note 15 at 794.
} 


\section{Appendix One}

\section{Investment treaty arbitration coding project}

Issues classification template (June 2009)

Coding of substantive issues

\begin{tabular}{|l|l|}
\hline Issue 8: “national treatment" - expansive approach" & Issue 8: “national treatment" - restrictive approach"
\end{tabular}

${ }^{90}$ Modeled on: (1) Occidental Exploration and Production Company v Republic of Ecuador (1 July 2004) 17(1)

World Trade and Arb Mat 165 (which found a violation of national treatment although the compared investments were not in like circumstances); (2) Pope and Talbot $v$ Canada, supra note 71 (which adopted a competition-based approach to like circumstances, presumed a violation based on initial evidence of de facto discrimination subject to broad exceptions, and rejected a proposed requirement for proof of disproportionate disadvantage); and (3) Saluka Investments BVv Czech Republic (17 March 2006) 18(3) World Trade and Arb Mat 166 (which required the state to justify any differential treatment).

${ }^{91}$ Modeled on: (1) United Parcel Service v Canada, supra note 71 (which adopted a relatively flexible approach to like circumstances); and (2) $A D F v U S A$, supra note 75 (which adopted a rigorous approach to the investor's evidentiary burden to establish de facto discrimination). 


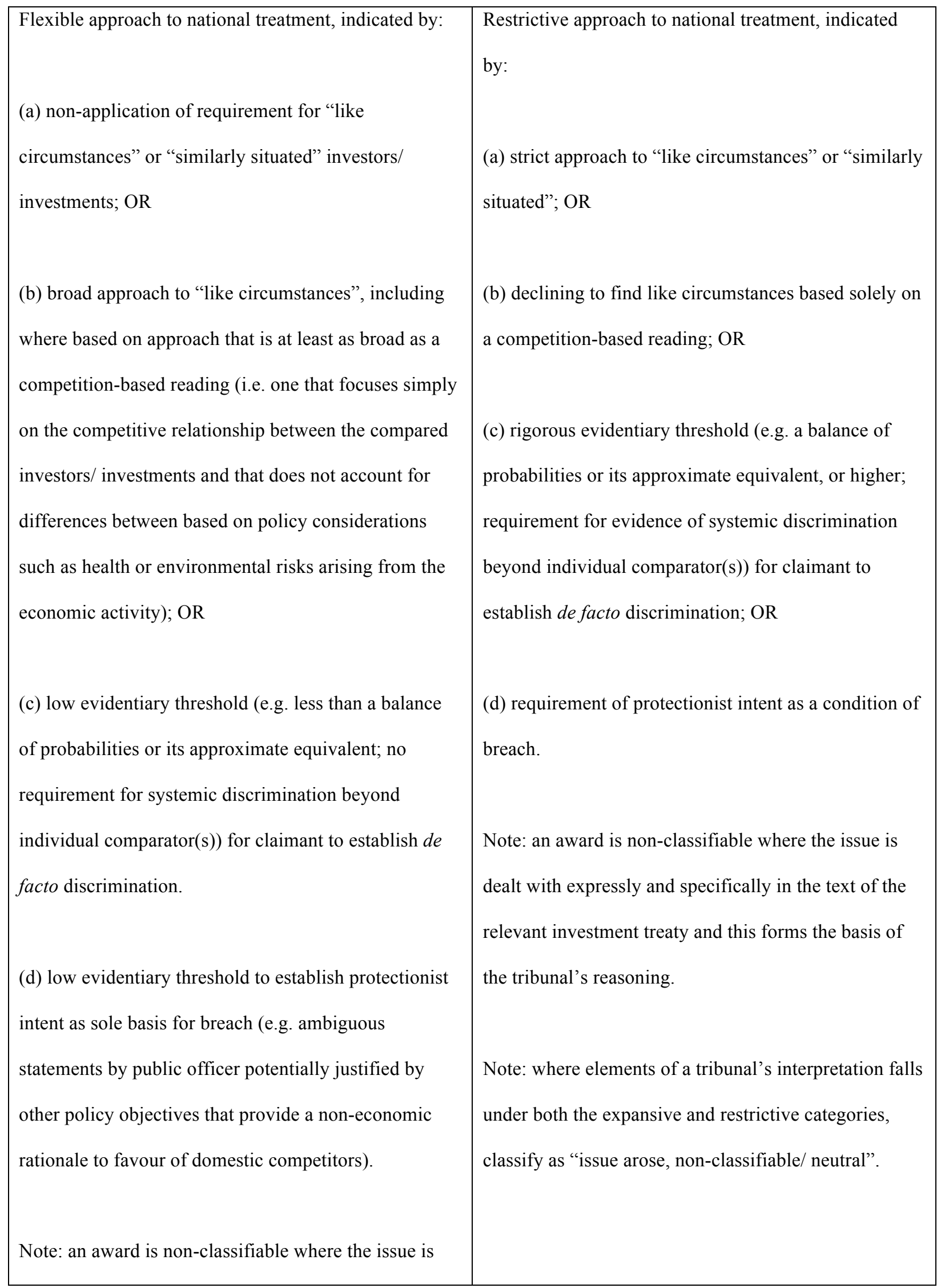




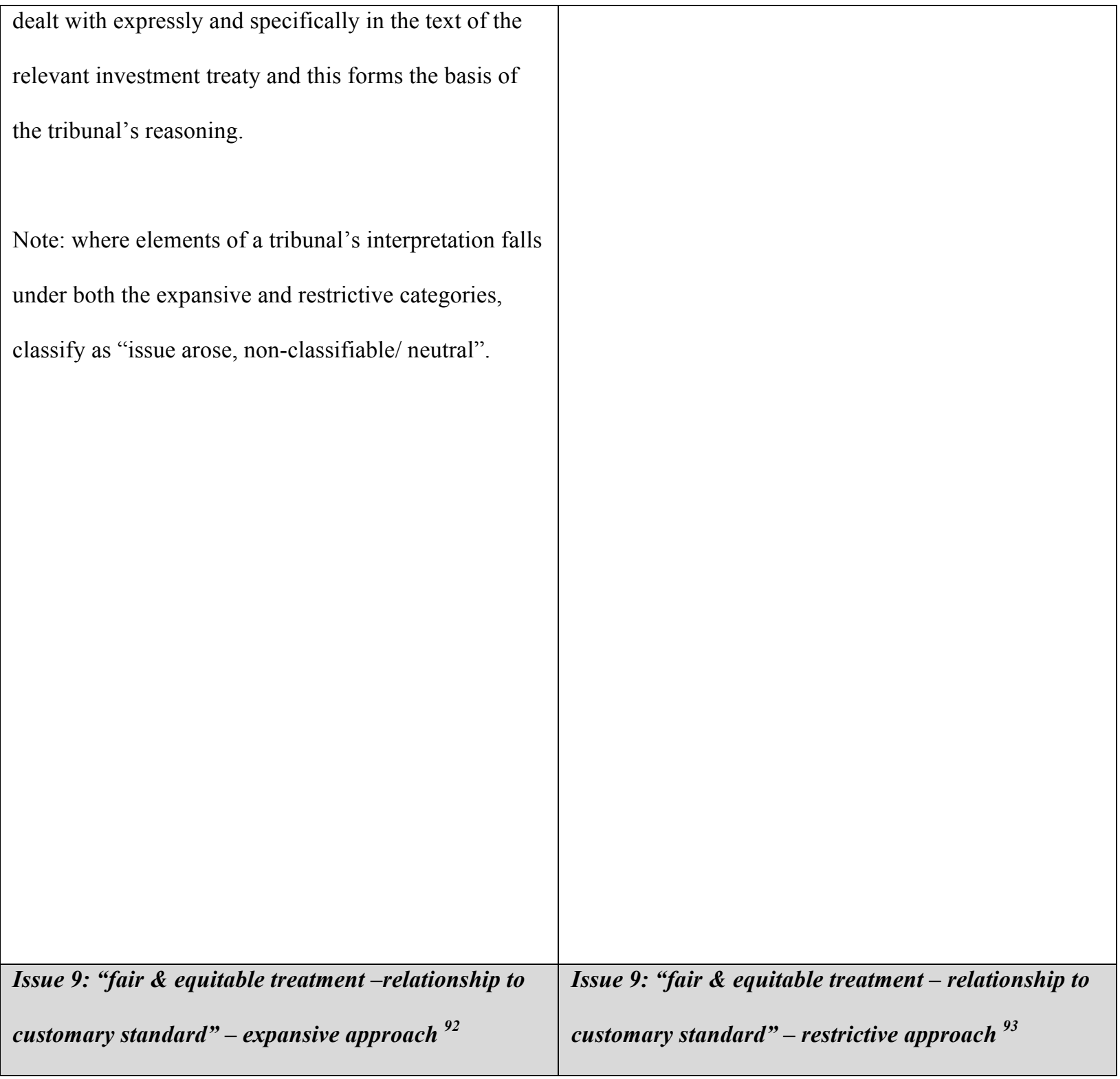

\footnotetext{
${ }^{92}$ Modeled on: (1) CMS Gas Transmission Company v Republic of Argentina (17 July 2003) 42 ILM 788 (which equated a broad version of fair and equitable treatment to the customary minimum standard); (2) Occidental v Ecuador, supra note 90 (which declined to limit fair and equitable treatment to the customary standard); and (3) Siemens AGv Argentine Republic (3 August 2004) 44 ILM 138 (which declined to limit fair and equitable treatment to the customary standard).

${ }^{93}$ Modeled on: (1) Noble Ventures $v$ Romania (12 October 2005) ICSID Case No ARB/01/11 (which limited fair and equitable treatment to the customary standard).
} 


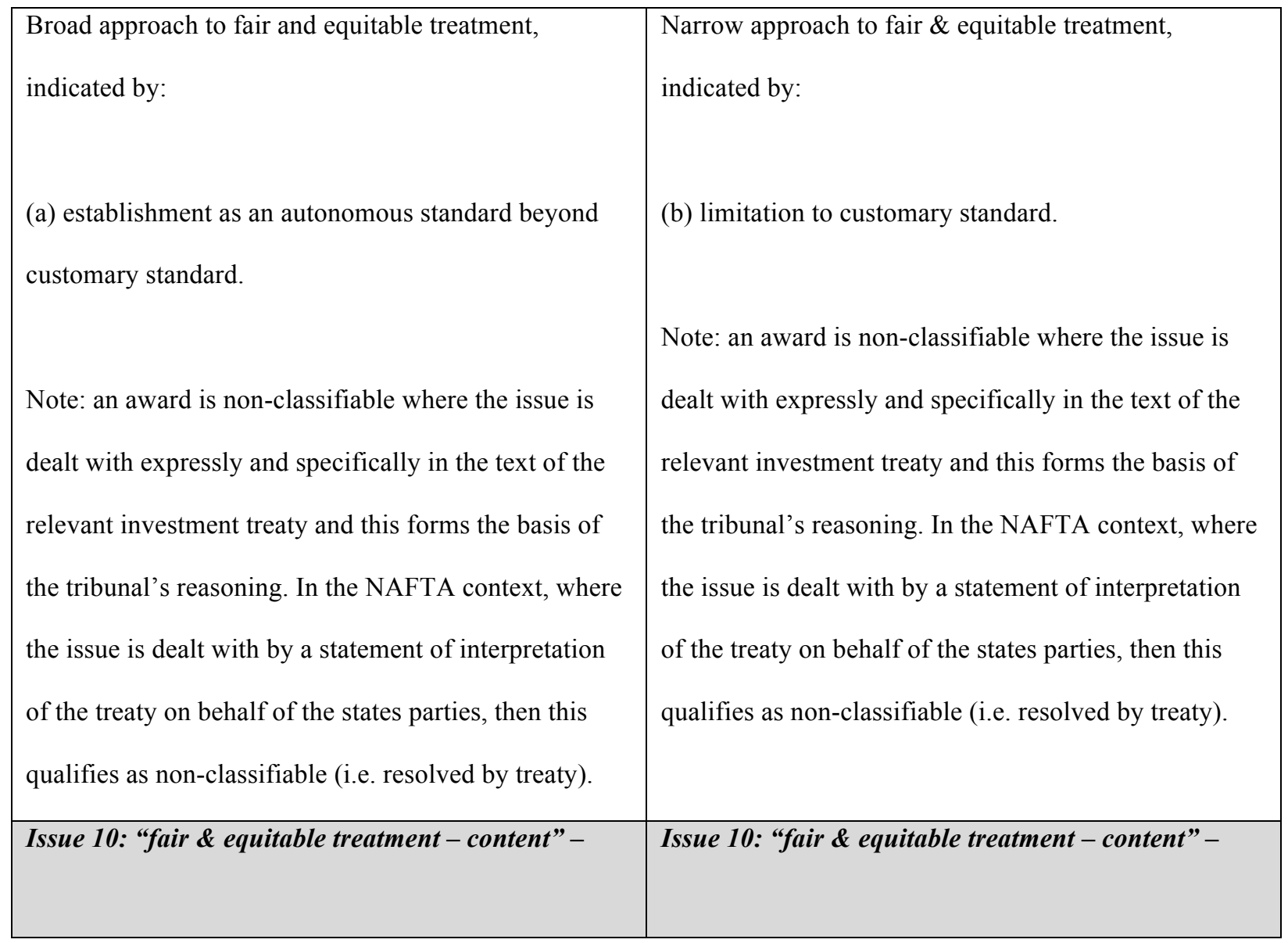




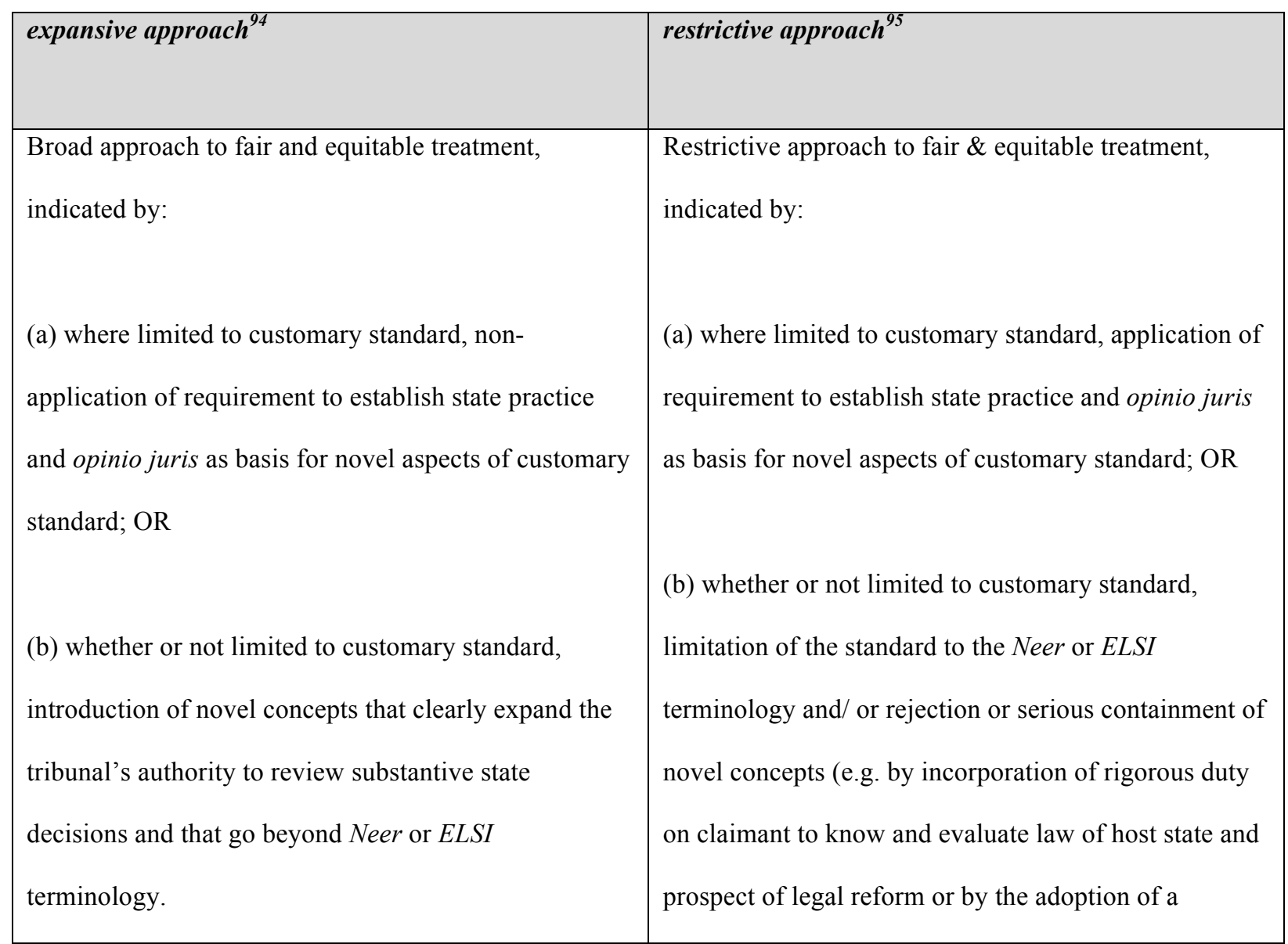

${ }^{94}$ Modeled on: (1) CMS v Argentina, supra note 92 (which concluded that arbitrary or discriminatory treatment in general would violate fair \& equitable treatment and went beyond Neer or ELSI language, supra note 36, required stability and predictability, precluded any need for bad faith in favour of an objective assessment of whether legitimate expectations of the foreign investor were met); (2) Occidental v Ecuador, supra note 90 (which approached fair and equitable treatment as an objective requirement not requiring bad faith and incorporated the concept of legal and business stability); (3) Sempra Energy International v Argentine Republic (11 May 2005) ICSID Case No ARB/02/16 (which incorporated concepts of legal stability and observance of legal obligations); (4) Siemens $v$ Argentina, supra note 92 (which broadened the Neer and ELSI language, incorporated the concept of legitimate expectations, and precluded any requirement for bad faith).

${ }^{95}$ Modeled on: (1) Genin (Alex) and Others v Republic of Estonia (25 June 2001) 17 ICSID Rev 395 (which limited the standard to the Neer and ELSI language, supra note 36); and (2) Noble Ventures v Romania, supra note 93 (which applied the ELSI standard). 

Note: the "Neer or ELSI terminology" is that of “outrage”, "bad faith", "willful disregard of due process of law", "willful neglect of duty", "an extreme insufficiency of action", "insufficiency of governmental action so far short of international standards that every reasonable and impartial man would readily recognize its insufficiency", or conduct that would "shock or at least surprise a sense of judicial propriety". 96

Note: "novel concepts" are indicated by such terminology as "idiosyncratic", "unreasonable", "legitimate expectations" (including incorporation of a strict duty of the host state to abide by specific undertakings as an umbrella-like component of fair and equitable treatment), stability of the legal and business framework, affirmative transparency obligations of the host state (without emphasis on the investor's duty to know and evaluate the law and to anticipate possible legal reforms), or breach of another international obligation, where the terminology is not limited by a strong statement of the need for deference wherever the host state has an objective basis for its decision. deferential position where host state has an objective basis for the decision).

Note: the "Neer or ELSI terminology" is that of “outrage", "bad faith", "willful disregard of due process of law", "willful neglect of duty", "an extreme insufficiency of action", "insufficiency of governmental action so far short of international standards that every reasonable and impartial man would readily recognize its insufficiency", or conduct that would "shock or at least surprise a sense of judicial propriety". 97

Note: "novel concepts" are indicated by such terminology as "idiosyncratic", "unreasonable", "legitimate expectations" (including incorporation of a strict duty of the state to abide by specific undertakings as an umbrella-like component of fair and equitable treatment), stability of the legal and business framework, affirmative transparency obligations of the host state (without emphasis on the investor's duty to know and evaluate the law and to anticipate possible legal reforms), or breach of another international obligation, where the terminology is not limited by a

\footnotetext{
${ }^{96}$ Supra note 36.

${ }^{97}$ Ibid.
} 


\begin{tabular}{|l|l|}
\hline $\begin{array}{l}\text { Note: an award is non-classifiable where the issue is } \\
\text { dealt with expressly and specifically in the text of the }\end{array}$ & $\begin{array}{l}\text { strong statement of the need for deference wherever the } \\
\text { host state has an objective basis for its decision. }\end{array}$ \\
$\begin{array}{l}\text { relevant investment treaty and this forms the basis of } \\
\text { the tribunal's reasoning. }\end{array}$ & $\begin{array}{l}\text { Note: an award is non-classifiable where the issue is } \\
\text { dealt with expressly and specifically in the text of the } \\
\text { relevant investment treaty and this forms the basis of } \\
\text { the tribunal's reasoning. }\end{array}$ \\
\hline $\begin{array}{l}\text { Issue 11: “full protection and security"-expansive } \\
\text { approach" }\end{array}$ & $\begin{array}{l}\text { Issue 11: “full protection and security" - restrictive } \\
\text { approach" }\end{array}$ \\
\hline
\end{tabular}

${ }^{98}$ Modeled on: (1) CME Republic BV v Czech Republic (13 September 2001) 14(3) World Trade and Arb Mat 109 (majority opinion) (which extended the standard to security and protection of the investment); (2) Ceskoslovenska Obchodni Banka v Slovak Republic (24 May 1999) 17(3) World Trade and Arb Mat 189 (which found a breach based on the state's conduct in the interpretation of contractual terms); and (3) Azurix Corp v Argentine Republic (14 July 2006) ICSID Case No ARB/01/12 (which extended the standard beyond protection against physical violence to create a state obligation to ensure a secure investment environment).

${ }^{99}$ Modeled on: (1) PSEG Global Inc v Republic of Turkey (4 June 2004) 44 ILM 465 (which limited the standard to physical safety); (2) Saluka v Czech Republic, supra note 90 (which limited the standard to civil strife and physical violence); and (3) Rumeli Telekom AS and Telsim Mobil Telekomunibasyon Hizmetleri AS v Kazakhstan (29 July 2008) ICSID Case No ARB/05/16 (which limited the standard to physical integrity without extending it to legal or economic security). 


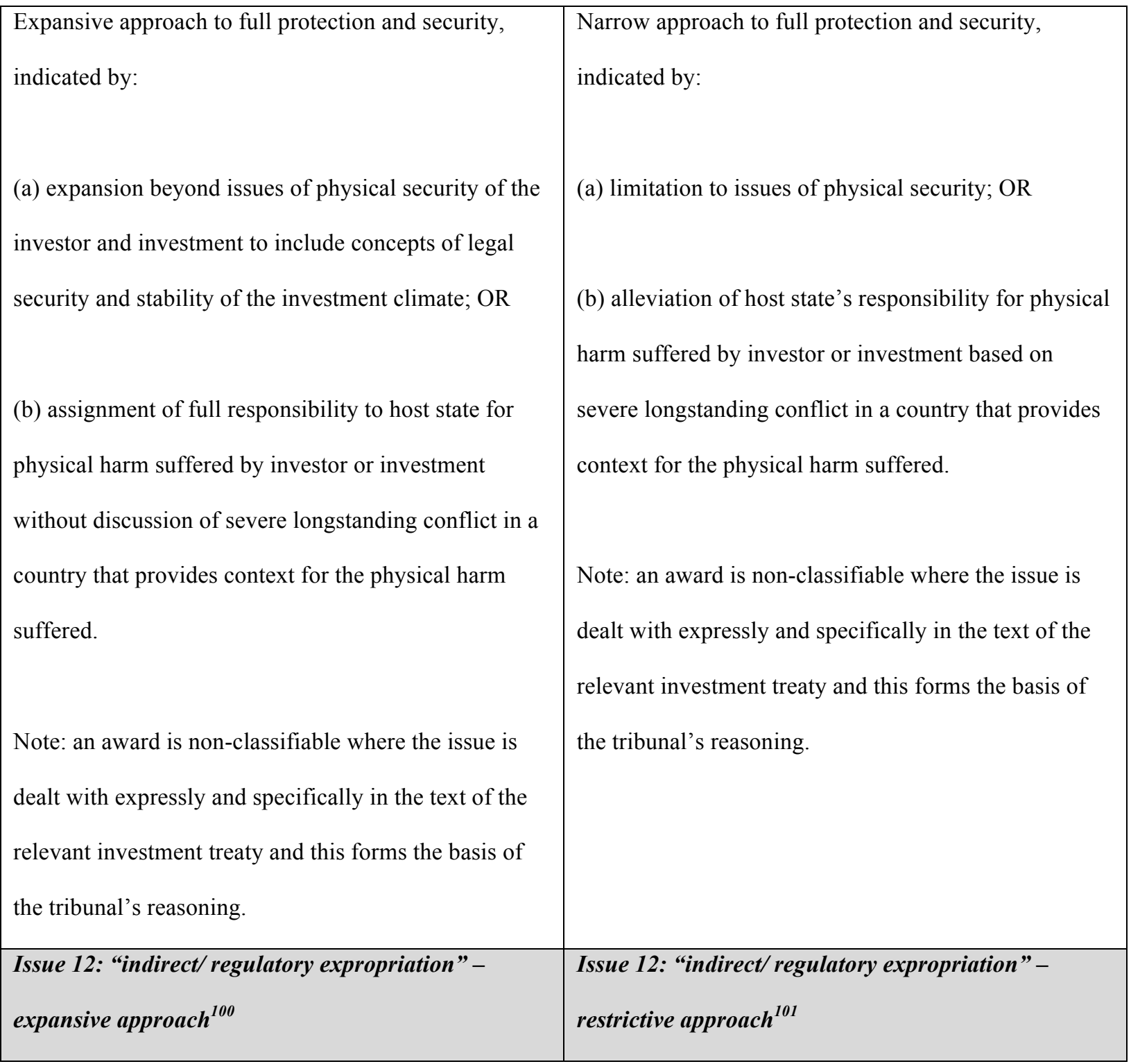

\footnotetext{
${ }^{100}$ Modeled on: (1) Metalclad $v$ Mexico, supra note 79 (which adopted an effects-based analysis and extended the concept of indirect expropriation to non-discriminatory measures passed for a public purpose regardless of specific commitments of the state); (2) Tecnicas Medioambientales Tecmed, SA v United Mexican States (29 May 2003$) 43$ ILM 133 (which disregarded the government's intentions and shifted the burden to the state to justify measure as proportionate); and (3) Biloune and Marine Drive Complex Ltd v Ghana Investments Centre and Government of Ghana (27 October 1989) UNCITRAL Rules tribunal (which declined to consider the regulatory aims of the state as a factor).
} 


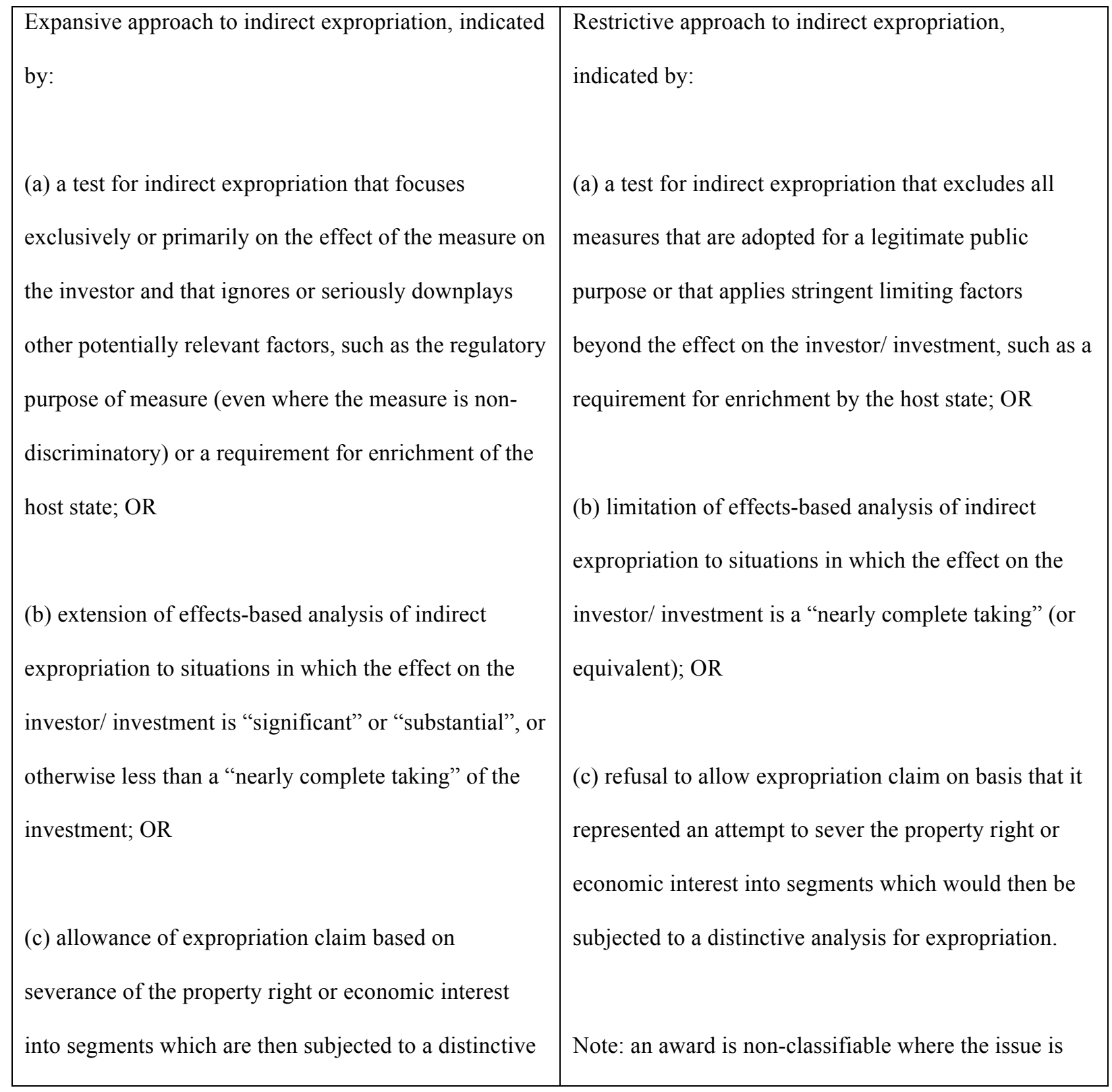

${ }^{101}$ Modeled on: (1) Methanex $v$ USA, supra note 67 (which declined to find an indirect expropriation where the measure was for a public purpose, non-discriminatory, and not in breach of a specific commitment of the state); (2) Olguín (Eudoro Armando) v Republic of Paraguay (26 July 2001) 18 ICSID Rev 143 (which declined to find an indirect expropriation arising from a mere omission of the state and without enrichment of the state); and (3) Lauder (Ronald S) v Czech Republic (3 September 2001) 4 World Trade and Arb Materials 35 (which required enrichment of the respondent state to find a violation). 


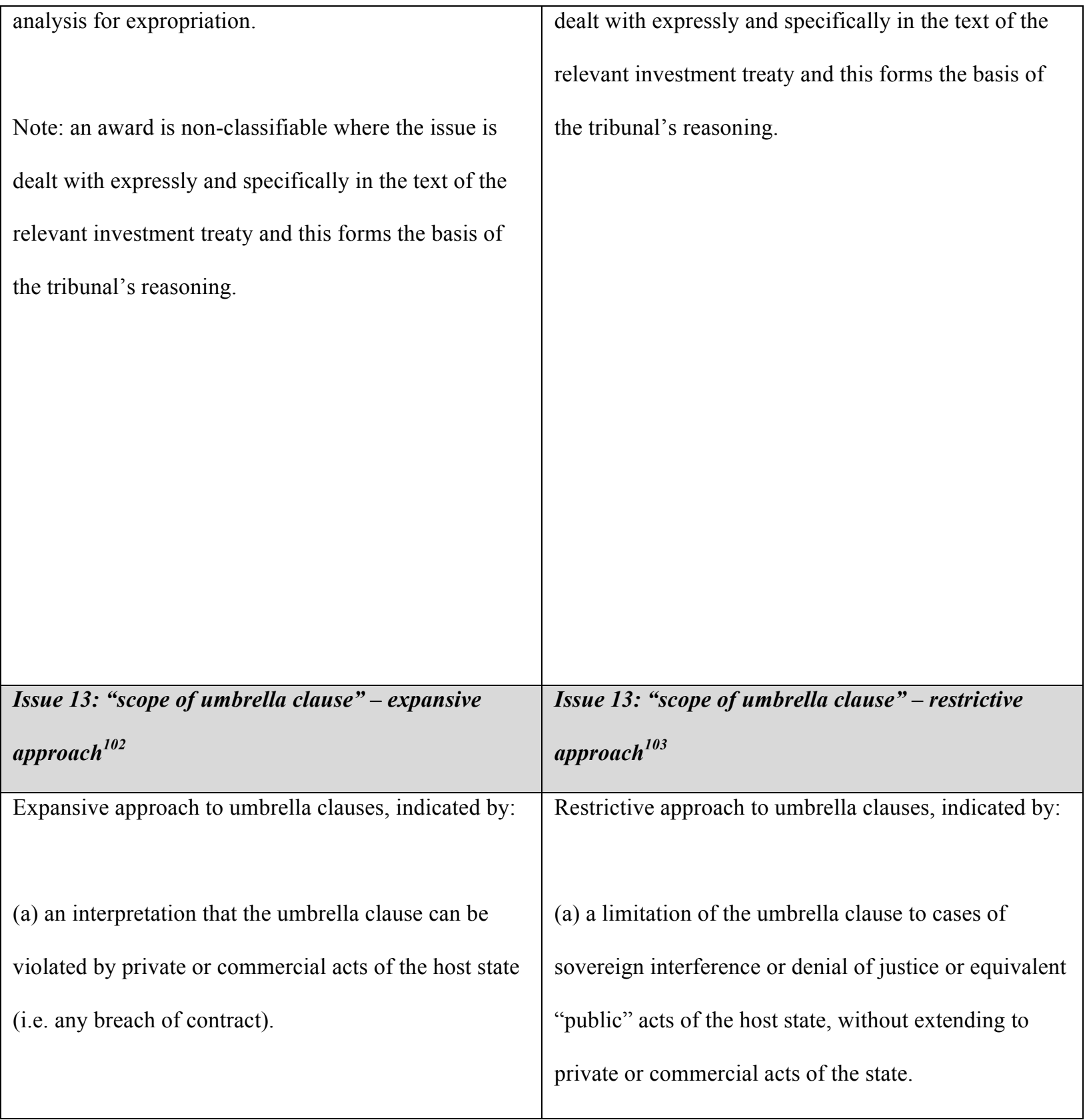

${ }^{102}$ Modeled on: Duke Energy Electroquil Partners \& Electroquil S.A. v Ecuador (18 August 2008) 20(6) World Trade Arbitration 189 (which extended the umbrella clause beyond situations of sovereign interference).

${ }^{103}$ Modeled on: (1) SGS Société Générale de Surveillance v Pakistan (6 August 2003) 42 ILM 1290 (which declined to extend the umbrella clause to domestic contractual obligations); and (2) Impregilo v Pakistan (22 April 2005) ICSID Case No ARB/03/3 (which concluded that the respondent state could only breach the treaty through acts of sovereign authority). 


\begin{tabular}{|c|c|}
\hline $\begin{array}{l}\text { Note: an award is non-classifiable where the issue is } \\
\text { dealt with expressly and specifically in the text of the } \\
\text { relevant investment treaty and this forms the basis of } \\
\text { the tribunal's reasoning. }\end{array}$ & $\begin{array}{l}\text { Note: an award is non-classifiable where the issue is } \\
\text { dealt with expressly and specifically in the text of the } \\
\text { relevant investment treaty and this forms the basis of } \\
\text { the tribunal's reasoning. }\end{array}$ \\
\hline $\begin{array}{l}\text { Issue 14: "essential/ national security" - expansive } \\
\text { approach }^{104}\end{array}$ & $\begin{array}{l}\text { Issue 14: "essential/ national security" - restrictive } \\
\text { approach }^{105}\end{array}$ \\
\hline $\begin{array}{l}\text { Narrow approach to essential or national security } \\
\text { exception, indicated by: }\end{array}$ & $\begin{array}{l}\text { Flexible approach to essential or national security } \\
\text { exception, indicated by: }\end{array}$ \\
\hline $\begin{array}{l}\text { (a) exclusion, from the scope of the exception, of } \\
\text { emergency measures to address a domestic financial } \\
\text { and economic crisis. }\end{array}$ & $\begin{array}{l}\text { (a) inclusion, within the scope of the exception, of } \\
\text { emergency measures to address a domestic financial } \\
\text { and economic crisis. }\end{array}$ \\
\hline $\begin{array}{l}\text { Note: an award is non-classifiable where the issue is } \\
\text { dealt with expressly and specifically in the text of the } \\
\text { relevant investment treaty and this forms the basis of } \\
\text { the tribunal's reasoning. }\end{array}$ & $\begin{array}{l}\text { Note: an award is non-classifiable where the issue is } \\
\text { dealt with expressly and specifically in the text of the } \\
\text { relevant investment treaty and this forms the basis of } \\
\text { the tribunal's reasoning. }\end{array}$ \\
\hline
\end{tabular}

\footnotetext{
${ }^{104}$ Modeled on: (1) CMS v Argentina, supra note 92; and (2) Sempra v Argentina, supra note 94 (both of which rejected Argentina's essential security defence).

${ }^{105}$ Modeled on: (1) Continental Casualty Company v Argentine Republic (22 February 2006) ICSID Case No ARB/03/9; and (2) LG\&E Energy Corp, LG\&E Capital Corp, and LG\&E International, INC. v Argentine Republic (3 October 2006) 46 ILM 40 (both of which partially allowed Argentina's essential security defence).
} 
Potential other appendices (technical, not necessary in my view, could be online only):

Table 7: Regression results of the model

\begin{tabular}{|c|c|c|c|c|}
\hline Coefficients & Estimate & Std.Error & t-value & p-value \\
\hline Intercept & 1.20 & 0.48 & 2.48 & 0.01 \\
\hline Claimant nationality:2 & 0.65 & 0.69 & 0.95 & 0.34 \\
\hline Claimant nationality:3 & -0.13 & 0.70 & -0.18 & 0.86 \\
\hline Claimant nationality:4 & 1.07 & 0.54 & 1.99 & 0.05 \\
\hline Claimant nationality:5 & 0.74 & 0.35 & 2.10 & 0.04 \\
\hline Specific issue: 2 & -26.68 & 51154.92 & 0.00 & 1.00 \\
\hline Specific issue: 3 & -0.85 & 0.44 & -1.92 & 0.06 \\
\hline Specific issue: 4 & -0.32 & 0.56 & -0.57 & 0.57 \\
\hline Specific issue:5 & -1.97 & 0.59 & -3.37 & 0.00 \\
\hline Specific issue:6 & -0.11 & 0.44 & -0.25 & 0.80 \\
\hline Specific issue:7 & -3.07 & 0.49 & -6.23 & $<.00001$ \\
\hline Specific issue: 8 & -3.52 & 0.48 & -7.31 & $<.00001$ \\
\hline Specific issue:9 & -2.60 & 0.49 & -5.30 & $<.00001$ \\
\hline Specific issue: 10 & -1.00 & 0.44 & -2.27 & 0.02 \\
\hline Specific issue: 11 & -4.19 & 0.50 & -8.42 & $<.00001$ \\
\hline Specific issue: 12 & -2.51 & 0.43 & -5.83 & $<.00001$ \\
\hline Specific issue: 13 & -0.62 & 0.64 & -0.97 & 0.33 \\
\hline Specific issue: 14 & -2.84 & 0.58 & -4.85 & $<.00001$ \\
\hline Treat category:2 & 0.64 & 0.64 & 1.00 & 0.32 \\
\hline
\end{tabular}




\begin{tabular}{|l|c|c|c|c|}
\hline Treat category:3 & -0.85 & 0.43 & -1.97 & 0.05 \\
\hline Treat category:4 & -0.76 & 1.42 & -0.54 & 0.59 \\
\hline Total Issue resolutions & 0.29 & 0.08 & 3.67 & 0.00 \\
\hline Total arbitrator appointments & 0.08 & 0.05 & 1.79 & 0.07 \\
\hline
\end{tabular}

Table 8: Effect sizes for individual predictors in the model

\begin{tabular}{|l|c|c|c|}
\hline \multicolumn{1}{|c|}{ Individual Predictor } & $\begin{array}{c}\text { Dataset } \\
\text { jurisdictional } \\
\text { issues }\end{array}$ & $\begin{array}{c}\text { Dataset } \\
\text { substantive } \\
\text { issues }\end{array}$ & $\begin{array}{c}\text { Dataset } \\
\text { cumulative }\end{array}$ \\
\hline Claimant's state of nationality & 0.08 & 0.08 & 0.09 \\
\hline Specific issue among coded issues & 0.08 & 0.06 & 0.06 \\
\hline Category of treaty or treaty type & 0.07 & 0.06 & 0.06 \\
\hline Total issue resolutions in the case & 0.02 & 0.03 & 0.03 \\
\hline Total appointments per arbitrator & 0.03 & 0.00 & 0.02 \\
\hline
\end{tabular}

